\title{
17. CHEMICAL COMPOSITION AND FORMATION OF A MASSIVE SULFIDE DEPOSIT, MIDDLE VALLEY, NORTHERN JUAN DE FUCA RIDGE (SITE 856) ${ }^{1}$
}

\author{
S. Krasnov, ${ }^{2}$ T. Stepanova, ${ }^{2}$ and M. Stepanov ${ }^{2}$
}

\begin{abstract}
Studies of sulfide cores from Site 856, Middle Valley, northern Juan de Fuca Ridge, established the vertical zonation of a large inactive oceanic massive sulfide deposit. Zone 1 consists mainly of pyritic massive sulfide with minor sphalerite and magnetite $(0$ to $28 \mathrm{mbsf}$ in Hole $856 \mathrm{H}$ and 0 to $40 \mathrm{mbsf}$ in Hole $856 \mathrm{G}$ ). Compared with the rest of the deposit, this zone is strongly enriched in $\mathrm{Zn}$ and a large number of trace metals (in particular $\mathrm{Cd}, \mathrm{Mn}, \mathrm{Sn}$, and $\mathrm{Sb}$ ), and in elements contained in gangue minerals ( $\mathrm{Si}, \mathrm{Al}$, $\mathrm{Mg}$, and $\mathrm{Ba}$ ). Most of these elements reach their maximum concentrations in the upper part of the zone; the lower part is enriched in $\mathrm{Cu}, \mathrm{Se}$, and $\mathrm{Ca}$. Zone 2 consists dominantly of pyrrhotite-rich massive sulfide with minor pyrite and magnetite ( 28 to $48 \mathrm{mbsf}$ in Hole $856 \mathrm{H}$ ) and is depleted in minor elements. Zone 3 is almost pure pyritic massive sulfide ( 48 to 75 mbsf in Hole $856 \mathrm{H}$ and 40 to $65 \mathrm{mbsf}$ in Hole 856G) and is relatively enriched in $\mathrm{Ge}, \mathrm{As}, \mathrm{Sb}, \mathrm{Pb}$, and $\mathrm{Tl}$. Zone 4 consists of dominant pyrrhotite with minor chalcopyrite ( 75 to $95 \mathrm{mbsf}$ in Hole $856 \mathrm{H}$ ) and shows a maximum enrichment in $\mathrm{Cu}, \mathrm{Co}$, and $\mathrm{Bi}$.

Correlation analysis shows that elements enriched in zone 1 are associated with different ore-forming and gangue minerals: sphalerite ( $\mathrm{Cd}$ and $\mathrm{Pb}$ ), talc and/or chlorite ( $\mathrm{Sc}, \mathrm{Th}$, and $\mathrm{REE})$, silica (Hg and $\mathrm{Ta})$, dolomite $(\mathrm{V})$, and barite $(\mathrm{Sr}, \mathrm{Zr}$, and $\mathrm{Hf}) . \mathrm{Sb}, \mathrm{As}$, $\mathrm{Sn}, \mathrm{Au}, \mathrm{Ag}, \mathrm{Mn}, \mathrm{Mo}$, and $\mathrm{Tl}$ form a separate association, presumably related to sulfosalt minerals.

Enrichment of $\mathrm{Zn}$ and minor elements in the upper part of the deposit, which is typical of ancient massive sulfide deposits, is attributed to the zone-refining process of progressive upward replacement of lower temperature minerals by higher temperature minerals during growth of the sulfide body, with the concomitant hydrothermal leaching of trace metals.

Later, the deposit was hydrothermally altered, probably due to lateral flow of evolved seawater along turbidite layers. The alteration produced replacement of primary pyrrhotite by pyrite in zone 3 and by pyrite + magnetite assemblages in the upper zones. In the upper levels of the deposit, sulfate-rich water acted as a strong oxidant. At lower levels a hotter and more evolved sulfur-enriched pyritizing solution also introduced additional $\mathrm{Pb}, \mathrm{Sb}, \mathrm{As}$, and other sediment-derived elements into zone 3 . The absence of light rare earth element enrichment and the existence of a positive Eu anomaly in the massive sulfides of this zone is connected with the alteration of plagioclase in the associated turbidites.

The secondary convection system that caused alteration of the massive sulfides could have been driven by one of the sills emplaced into Middle Valley sediments subsequent to sulfide formation.
\end{abstract}

\section{INTRODUCTION}

During Leg 139 of the Ocean Drilling Program (ODP) a large body of massive sulfides was drilled in the rift valley (Middle Valley) of the Endeavour Segment, northern Juan de Fuca Ridge. With the exception of several relatively shallow holes drilled during Leg 106 wit $^{\text {L }}$ in the Snake Pit Hydrothermal Field in the Atlantic (Honnorez et al., 1990), this was the first opportunity to core an oceanic sulfide deposit and study its inner structure.

Similar massive sulfides within sedimentary-volcanic sequences, genetically related to mafic volcanic rocks, are commonly referred to as Besshi-type deposits (Franklin et al., 1981). These deposits comprise an important group of ancient volcanogenic massive sulfides, which have been actively studied and mined on land. Therefore, information on the structure of these modern equivalents is of primary importance for understanding the genesis of economically significant base-metal deposits.

The aim of this paper is to describe the chemical compositions of the recovered massive sulfides, compare them to those of other oceanic sulfide deposits, and discuss possible genetic implications.

\section{GEOLOGIC SETTING}

Hydrothermal vents and massive sulfide deposits of the northern Juan de Fuca Ridge are situated in Middle Valley, a 15-km-wide, sediment-filled abandoned rift valley. Heat-flow anomalies in excess

\footnotetext{
${ }^{1}$ Mottl, M.J., Davis, E.E., Fisher, A.T., and Slack, J.F. (Eds.), 1994. Proc. ODP, Sci. Results, 139: College Station, TX (Ocean Drilling Program).

${ }^{2}$ Institute for Geology and Mineral Resources of the Ocean, 1 Maklin Ave., 190121. St. Petersburg, Russia.
}

of $1 \mathrm{~W} / \mathrm{m}^{2}$ were discovered in the eastern part of the valley between $48^{\circ} 20^{\prime} \mathrm{N}$ and $48^{\circ} 30^{\prime} \mathrm{N}$ (Davis et al., 1987). A hydrothermal origin has been suggested for a number of mounds in Middle Valley, each several hundred meters across and up to $60 \mathrm{~m}$ high, which were found by SeaMARC-I acoustic imagery in this area (Davis et al., 1987). A shallow core, taken at the base of one of the mounds during the 1985 cruise of C.H.S. Parizeau, contained $2.4 \mathrm{~m}$ of sediments rich in disseminated sulfides and massive sulfide clasts (Goodfellow and Blaise, 1988).

Later photographic and video studies and subsequent sampling documented the presence of extensive massive sulfide outcrops along the margins of the mounds, which confirmed the large scale of the deposits. Little hydrothermal venting was discovered in the area, and the sulfide deposits are mostly relict. However, another area with numerous high-temperature vents of the black and white smoker type was found about $3 \mathrm{~km}$ to the northwest, closer to the axis of the valley (Kappel and Franklin, 1989).

During ODP Leg 139, eight holes were drilled at Site 856 in the mound area, near where the Middle Valley sulfides were first sampled in 1985 (Shipboard Scientific Party, 1992). Two holes (856A and 856B) were drilled into Bent Hill, a large mound typical of several in the area. This mound appeared to be covered by more than $100 \mathrm{~m}$ of undisturbed sediments that were uplifted by sill intrusion. In Hole $856 \mathrm{~B}$, at the southern edge of Bent Hill, massive sulfide clasts were recovered in the sediment column at a depth of about $30 \mathrm{~m}$. Six more holes were drilled at Site $856(856 \mathrm{C}$ to $856 \mathrm{H})$ within a sulfide mound that is up to $100 \mathrm{~m}$ in diameter and $20 \mathrm{~m}$ high, lying immediately to the south of Bent Hill. These holes are distributed over a distance of $60 \mathrm{~m}$ across the southern flank of the sulfide mound, but none reached the base of the deposit. Drilling of the deepest hole $(856 \mathrm{H})$ was terminated for technical reasons at $94 \mathrm{~m}$ below seafloor (mbsf), or 
Table 1. Comparison between certified and measured element concentrations $(\%)$ in the standard samples, used in atomic absorption analyses at VNIIoceangeologia.

\begin{tabular}{|c|c|c|c|c|c|c|c|}
\hline \multirow[b]{2}{*}{ Standard } & \multicolumn{7}{|c|}{ Element concentrations, measured (top) and certified (bottom) } \\
\hline & $\mathrm{Fe}$ & Mn & $\mathrm{Cu}$ & $\mathrm{Zn}$ & $\mathrm{Cd}$ & $\mathrm{Ca}$ & $\mathrm{Mg}$ \\
\hline SNK-1 & $\frac{18.67 \pm 0.13}{19.09}$ & & & & & & \\
\hline SNK-2 & $\frac{4.01 \pm 0.00}{4.07}$ & $\frac{0.173 \pm 0.007}{0.16}$ & $\frac{0.40 \pm 0.00}{0.39}$ & $\frac{0.038 \pm 0.001}{0.039}$ & & & \\
\hline$\# 3031$ & $\frac{10.15 \pm 0.24}{10.24}$ & $\begin{array}{c}0.21 \pm 0.00 \\
0.21\end{array}$ & $\frac{3.38 \pm 0.08}{3.37}$ & & & $\frac{20.00}{20.04}$ & $\frac{0.86 \pm 0.002}{0.80}$ \\
\hline \#08 & $\frac{16.26 \pm 0.54}{16.38}$ & & & $\frac{10.40 \pm 0.10}{10.39}$ & & & \\
\hline$\# 681$ & & & & $\frac{1.18 \pm 0.02}{1.23}$ & & & \\
\hline$\# 710$ & & & $\frac{12.62 \pm 0.12}{12.50}$ & $\frac{6.43 \pm 0.07}{6.55}$ & & & \\
\hline RUS-3 & & & & & $\frac{0.0037 \pm 0.0003}{0.0035}$ & & \\
\hline \#2891 & & & & & $\frac{0.0028 \pm 0.0001}{0.0029}$ & & \\
\hline ST-1 & & & & & & $\frac{7.29}{7.29}$ & $\frac{3.43 \pm 0.07}{3.44}$ \\
\hline
\end{tabular}

Note: Certified concentrations are from Chemyakhovskaya and Osyko (1983). Measured concentrations are average values of two to three individual determinations.

$2518 \mathrm{~m}$ below sea level (mbsl). This is much deeper than the level of the seafloor near the mound.

\section{ANALYTICAL METHODS}

All chemical analyses were carried out in St. Petersburg. $\mathrm{SiO}_{2}$ and $\mathrm{Al}_{2} \mathrm{O}_{3}$ were analyzed by photometry at the Institute for Geology and Mineral Resources of the Ocean (VNIIoceangeologia) by N. Luneva. The samples were decomposed by melting with sodium carbonate and borax. Silica was determined by the reduction product of yellow silica molybdenum heteropolyacid complex, with ascorbic acid used as a reducer. Aluminum oxide was determined using alumocreson, an ammonia salt of dioxytricarbonic acid of triphenylmethane row. Sulfur was determined gravimetrically, by means of precipitation with barium chloride.

$\mathrm{Fe}, \mathrm{Mn}, \mathrm{Cu}, \mathrm{Cd}, \mathrm{Ca}$, and $\mathrm{Mg}$ were also analyzed at VNIloceangeologia by N. Luneva, using atomic absorption spectrometry (C-115 spectrophotometer with flame atomization), with preliminary acidic treatment. Certified standards were used for control (Table 1).

$\mathrm{Zn}, \mathrm{Pb}, \mathrm{Mo}$, and $\mathrm{Ti}$ were determined by the same method, by $\mathrm{S}$. Shishkova and Ye. Chikhacheva at the Russian Geological Institute (VSEGEI). A Perkin Elmer M 305 spectrophotometer with flame atomization was used for the determination of $\mathrm{Zn}$ and $\mathrm{Pb}$. A Perkin Elmer M 603 with electrothermic atomization was used for Mo analyses, and an AAS-3 spectrophotometer with electrothermic atomization was used for Ti determination. Comparison between certified and measured concentrations in the standards, analyzed by atomic absorption at VSEGEI, is given in Table 2.

$\mathrm{Sr}, \mathrm{Sn}, \mathrm{Bi}, \mathrm{V}, \mathrm{Ge}$, and $\mathrm{Tl}$ were analyzed by Ye. Khitric (VNIIoceangeologia) by quantitative optical emission spectrometry, using a DFS-13 spectrograph with a flat grating ( 600 lines $/ \mathrm{mm})$. The working range was $200-1000 \mathrm{~nm}$, relative aperture 1:40, and linear dispersion $0.4 \mathrm{~nm} / \mathrm{mm}$. Certified and measured element concentrations in the standards used are given in Table 3 .

A wide range of minor elements was determined by 1 . Shtangeeva (St. Petersburg State University) by instrumental neutron activation analysis (INAA): $\mathrm{Ag}, \mathrm{Au}, \mathrm{As}, \mathrm{Sb}, \mathrm{Co}, \mathrm{Ni}, \mathrm{Sc}, \mathrm{Cr}, \mathrm{Zr}, \mathrm{Cs}, \mathrm{Rb}, \mathrm{Ba}, \mathrm{Hf}, \mathrm{Ta}$, $\mathrm{Th}, \mathrm{U}, \mathrm{Se}, \mathrm{Hg}, \mathrm{La}, \mathrm{Ce}, \mathrm{Sm}, \mathrm{Eu}, \mathrm{Tb}$, and $\mathrm{Yb}$. The samples and stand-
Table 2. Comparison between certified and measured element concentrations in the standard samples, used in atomic absorption analyses at VSEGEI.

\begin{tabular}{|c|c|c|c|c|}
\hline \multirow[b]{2}{*}{ Standard } & \multicolumn{4}{|c|}{$\begin{array}{l}\text { Element concentrations, measured (top) and certified } \\
\text { (bottom) }\end{array}$} \\
\hline & $\mathrm{Zn}(\%)$ & $\mathrm{Pb}(\mathrm{ppm})$ & Mo (ppm) & Ti (ppm) \\
\hline RUS-1 & $\frac{3.39 \pm 0.04}{3.49}$ & & & \\
\hline ST-2 & $\frac{0.0112 \pm 0.0012}{0.0112}$ & & & \\
\hline SDPS-3 & & $\frac{253 \pm 23}{250}$ & & \\
\hline BM & & $\frac{12.3 \pm 0.7}{13}$ & & \\
\hline SKR-3 & & & $\frac{10.7 \pm 0.7}{13}$ & \\
\hline SG-1A & & & & $\frac{436 \pm 26}{430}$ \\
\hline
\end{tabular}

ards were irradiated with epithermal neutrons at a flux density of $5 \times$ $10 \mathrm{n} / \mathrm{cm}^{2} \mathrm{~s}$ for two days. Measurements were carried out by means of a $\mathrm{Ge}(\mathrm{Li})$ detector (resolution $2.1 \mathrm{keV}$ for line $13332 \mathrm{keV}$ ). Results of INAA for the standard samples are given in Table 4. The method of inner standard (Vaganov, 1975) was used for $\mathrm{Au}, \mathrm{Ag}, \mathrm{As}, \mathrm{Hg}, \mathrm{Ni}$, and Se determinations.

X-ray diffraction was conducted by M. Ostroumov (St. Petersburg Mining Institute), using DRON-2 (V=30 kV, I = $10 \mathrm{ma})$ and URS50 -IM (V $=15-20 \mathrm{kV}, \mathrm{I}=3-4 \mathrm{ma})$ diffractometers. Electron microprobe analyses were conducted by $\mathrm{O}$. Yakovleva (VSEGEI), using a Cameca MS-46 instrument. The detection limit was $0.01 \%$, with the relative analytical error of $2 \%$ for major elements. The ZAF correction method was used in data processing. 
Table 3. Comparison between certified and measured element concentrations ( $\mathrm{ppm}$ ) in the standard samples, used in quantitiative optical emission spectrometry.

\begin{tabular}{lcccccc}
\hline \multicolumn{5}{c}{ Element concentrations, measured (top) and certified (bottom) } \\
Standard & $\mathrm{Bi}$ & $\mathrm{Ge}$ & $\mathrm{Sr}$ & $\mathrm{Sn}$ & $\mathrm{Tl}$ & $\mathrm{V}$ \\
\hline SG-1A & $\frac{1.7 \pm 0.4}{2.0}$ & $\frac{3.5 \pm 0.1}{3.3}$ & $\frac{<100}{20}$ & $\frac{8.6 \pm 2.5}{3.3}$ & $\frac{6.7 \pm 0.7}{7.0}$ & $\frac{5 \pm 0}{5}$ \\
& $\frac{268 \pm 18}{270} \frac{3.8 \pm 0.5}{3.5}$ & & $\frac{322 \pm 12}{320}$ \\
ST-1A & $\frac{232 \pm 18}{230} \frac{3.8 \pm 0.6}{3.7}$ & & \\
SGD-1 & & & & & \\
\end{tabular}

Note: Certified element concentrations are from Chemyakhovskaya and Osyko (1983). Measured concentrations are average values of three to four individual determinations.

\section{MINERAL COMPOSITION AND STRUCTURE OF THE MASSIVE SULFIDE DEPOSIT}

Results of detailed ore petrology studies of the massive sulfide deposits are given by Duckworth et al. (this volume). We studied and consider here mainly the distribution of the major minerals, which directly determine the chemical composition of the ores, across the drilled section of the massive sulfide deposit.

Vertical changes in the mineralogy of the core from the deepest (95 mbsf) and most extensively sampled hole (856H; Fig. 1) are described herein. The percentage of core recovery and quantity of massive sulfide samples do not allow us to describe these changes in detail. However, certain trends in mineral distribution can be traced that make it possible to divide the deposit into several zones.

\section{Zone 1}

Massive sulfides from the upper part of the deposit, to about 28 mbsf, are the most complex in composition. They consist of pyrite as the dominant mineral, together with pyrrhotite, sphalerite, and magnetite in different proportions, and with minor quantities of marcasite, chalcopyrite, and isocubanite. Chlorite, talc, dolomite, and amorphous silica are the main gangue minerals; barite occurs in minor amounts. The uppermost part of the deposit (Core 139-856H-1R) was destroyed in the course of drilling. The resultant disintegrated mass was sorted by grain size during drilling, from fine-grained clayey sand in the upper part to coarse-grained sand with gravel and separate clay lumps in the lower part. The sands contain clasts of massive, cavernous, partly oxidized sulfides up to $4 \mathrm{~cm}$ in size. The $15-\mathrm{cm}$-long lowermost interval of Core $139-856 \mathrm{H}-1 \mathrm{R}$ consists almost totally of this massive sulfide debris, which resembles clasts recovered from conventional black smoker chimneys (e.g., Krasnov et al., 1992).

The pyrite from Core $139-856 \mathrm{H}-1 \mathrm{R}$ typically forms round, roselike aggregates, intergrown with gangue minerals. Traces of primary pyrrhotite, most of which is replaced by pyrite, occur locally. Subhedral sphalerite is interstitial and dispersed in the matrix of gangue minerals. The sphalerite contains tiny chalcopyrite inclusions oriented in one direction. Chalcopyrite (locally with isocubanite) and pyrrhotite also occur as isolated grains. Marcasite is intergrown with pyrite, replacing pyrrhotite. Rhombic barite crystals and crystal aggregates, and dark-brown grains of hydroxides, are also present. Talc and silica locally replace the clayey sediment matrix.

The largest sulfide clasts are composed of tabular pyrrhotite crystals up to $0.1 \mathrm{~mm}$ in size, forming a framework with interstitial sphalerite. In some of the clasts pyrrhotite is totally replaced by pyrite (Fig. 2). Clasts are commonly semioxidized.
Table 4. Comparison between certified and measured element concentrations (ppm) in the standard samples AGV-1, used in neutron-activation analyses.

\begin{tabular}{lcc}
\hline Element & $\begin{array}{c}\text { Certified } \\
\text { concentrations }\end{array}$ & $\begin{array}{c}\text { Measured } \\
\text { concentrations }\end{array}$ \\
\hline $\mathrm{Ba}$ & 1221.0 & $1240 \pm 60$ \\
$\mathrm{Co}$ & 15.2 & $15.0 \pm 0.8$ \\
$\mathrm{Cr}$ & 12.0 & $9.5 \pm 0.5$ \\
$\mathrm{Cs}$ & 1.26 & $1.50 \pm 0.08$ \\
$\mathrm{Hf}$ & 5.1 & $5.4 \pm 0.3$ \\
$\mathrm{Rb}$ & 67.0 & $65 \pm 3$ \\
$\mathrm{Sb}$ & 4.4 & $5.0 \pm 0.2$ \\
$\mathrm{Se}$ & 12.1 & $13.4 \pm 0.7$ \\
$\mathrm{Ta}$ & 0.91 & $0.90 \pm 0.04$ \\
$\mathrm{Th}$ & 6.5 & $6.4 \pm 0.3$ \\
$\mathrm{U}$ & 1.89 & $1.75 \pm 0.09$ \\
$\mathrm{Zr}$ & 225.0 & $240 \pm 12$ \\
$\mathrm{La}$ & 35.9 & $37.0 \pm 1.8$ \\
$\mathrm{Ce}$ & 64.9 & $65.0 \pm 3.0$ \\
$\mathrm{Sm}$ & 6.1 & $6.1 \pm 0.3$ \\
$\mathrm{Eu}$ & 1.71 & $1.76 \pm 0.09$ \\
$\mathrm{~Tb}$ & 0.79 & $0.80 \pm 0.04$ \\
$\mathrm{Yb}$ & 1.73 & $1.75 \pm 0.09$ \\
\hline $\mathrm{Ce}$ & & \\
\hline
\end{tabular}

Note: Certified concentrations are from Baedecker and McKown (1970). Measured concentrations are averages of five individual determinations, using the BCR-1 standard.

The sulfides of zone 1 in Core $139-856 \mathrm{H}-2 \mathrm{R}$ and the following cores are massive. Major minerals are pyrite, magnetite, and sphalerite with a variable pyrrhotite content, and small amounts of chalcopyrite. Abundant gangue minerals (dolomite, local silica, and traces of talc) form veins and are characteristic of the zone. Two generations of pyrite can be recognized: anhedral pyrite that is intergrown with tiny, oriented magnetite grains, and a subhedral variety that lacks magnetite intergrowths. Another form of magnetite occurrence is thin spongy intergrowths with gangue minerals. Sphalerite forms subhedral crystals that vary in size from 0.05 to $1 \mathrm{~mm}$ and are partly dispersed in massive sulfide and partly grouped in blebs. The largest grains occur in veins, together with pyrite and dolomite. Traces of pyrrhotite replacement by pyrite are evident in zone 1 . The two pyrite generations reflect successive stages of the replacement process. The paragenetically earlier generation involved the pseudomorphic replacement of tabular crystals of pyrrhotite by pyrite, intergrown with magnetite. Pyrite of the younger generation, associated with sphalerite, replaces both pyrrhotite relicts and early pyrite-magnetite aggregates. Only general outlines of the replaced pyrrhotite crystals are seen in the resultant structure (Fig. 3).

The upper meter of Core $139-856 \mathrm{H}-4 \mathrm{R}$ (at about $27 \mathrm{mbsf}$ ) is a sedimentary layer heavily veined with sulfide minerals and magnetite. The altered sediment consists of chlorite with minor talc and traces of siderite and dolomite rimming pyrite veins. Crystals of hexagonal pyrrhotite form sheaflike aggregates between pyrite crystals in veins and are dispersed in the sediment, along with minor sphalerite and chalcopyrite. Sporadic large sphalerite crystals (up to $0.2 \mathrm{~mm}$ ) occur in veins. The spongy magnetite is mostly intergrown with dolomite.

\section{Zone 2}

Massive sulfides of zone 2 (to about $48 \mathrm{mbsf}$ ) are characterized by the dominance of pyrrhotite, which forms a framework of elongated plates up to $3 \mathrm{~mm}$ in length. Based on X-ray diffraction data, pyrrhotite is mostly hexagonal, and partly monoclinic. The crystals of pyrrhotite are overgrown and partly replaced by pyrite (Fig. 4), the second most abundant mineral. Pyrite also fills interstitial spaces, forming large (up to $1.5 \mathrm{~mm}$ ) anhedral grains, and occurs in thin ramifying veins. Marcasite is locally present together with pyrite, forming rims and overgrowths on pyrrhotite. Anhedral sphalerite grains, up to $1 \mathrm{~mm}$ in size, fill the interstitial spaces. Small, mostly anhedral chalcopyrite grains fill the interstices and form tiny (up to $0.1 \mathrm{~mm}$ ) inclusions in pyrrhotite and sphalerite. 
Hole $139-856 \mathrm{H}$

Hole 139-856G

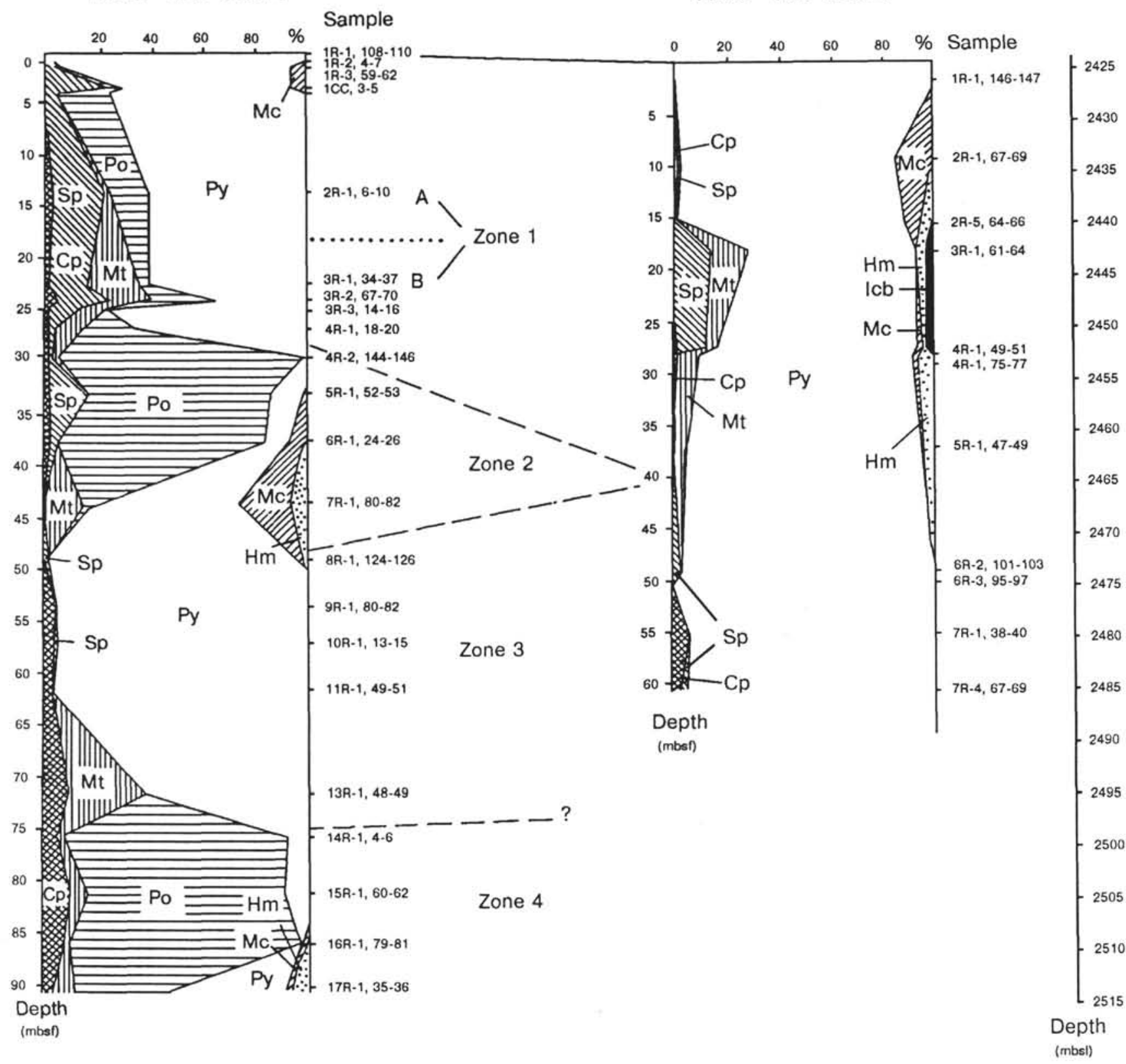

Figure 1. Mineral composition (percentage of total ore minerals) and zonation of sulfide cores from Holes $856 \mathrm{G}$ and $856 \mathrm{H}$. Py $=$ pyrite, $\mathrm{Po}=$ pyrrhotite, $\mathrm{Mt}=$ magnetite, $\mathrm{Sp}=$ sphalerite, $\mathrm{Cp}=$ chalcopyrite, $\mathrm{Ic}=$ isocubanite, $\mathrm{Mc}=$ marcasite, and $\mathrm{Hm}=$ hematite.

Magnetite occurrences in zone 2 are different from those in zone 1. The intergrowth of magnetite with pyrite is atypical, and more commonly it forms subhedral crystals in pyrrhotite and spongy, mossy aggregates of skeletal crystals in cavities (Fig. 5). Gangue minerals, represented mostly by chlorite, with minor carbonates and local silica and barite, are less abundant than in zone 1 . The lower part of zone 2 (Core 139-856H-7R) forms a transition to zone 3. Typical of this transition is Sample 139-856H-7R-1,80-82 cm, where fine-grained pyrite forms boxwork textures including overgrowths and partial replacements of pyrrhotite. Magnetite and hematite are associated with the newly formed pyrite, and occur in thin veinlets. Abundant fine anhedral grains of marcasite, intergrown with pyrite in its finest aggregates, are also characteristic of this core. Sphalerite and chalcopyrite are rare. Carbonate content is higher than that in the upper part of zone 2.

\section{Zone 3}

To about 75 mbsf, the core from Hole $856 \mathrm{H}$ consists of almost pure pyrite. Different types of pyrite aggregates in this zone form a thick megascopic framework (on the scale of several millimeters), and cells are either void or filled with gangue minerals, mostly amorphous silica and talc. Colloform, banded, and embayed pyrite textures are common. Structures that display local pyrrhotite replacement can also be seen, although pyrite is mainly recrystallized (Fig. 6). Small quantities of sphalerite and chalcopyrite are dispersed in pyrite.

Strong enrichment in barite is seen in Sample 139-856H-8R-1, $124-126 \mathrm{~cm}$. Barite crystals are overgrown by euhedral pyrite and radial aggregates of hematite (Fig. 7). A talc aggregate, partly replaced by pyrite and magnetite, occurs in the lower part of zone 3 


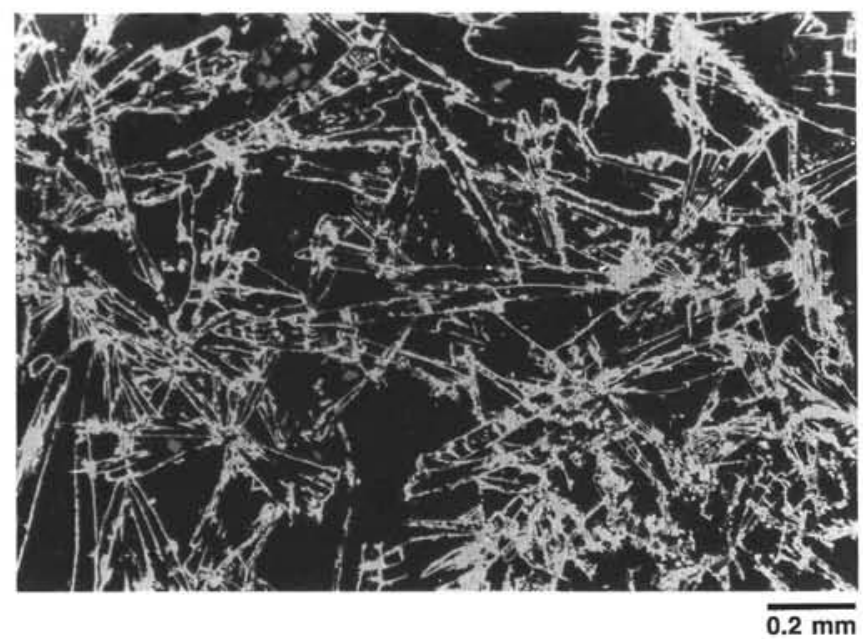

Figure 2. Boxwork texture of pyrite, growing over dissolved pyrrhotite crystals. Photomicrograph in reflected light, Sample $139-856 \mathrm{H}-16 \mathrm{R}-1,108-110 \mathrm{~cm}$.

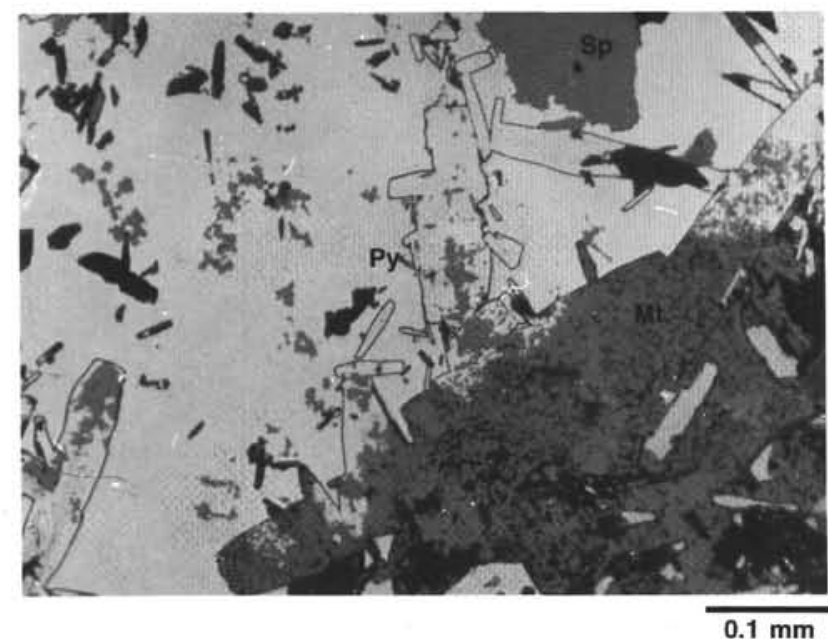

Figure 3. Outlines of tabular crystals of pyrrhotite, totally replaced by pyrite (Py), sphalerite (Sp), and magnetite (Mt). Photomicrograph in reflected light, Sample 139-856H-3R-2, 67-70 cm.

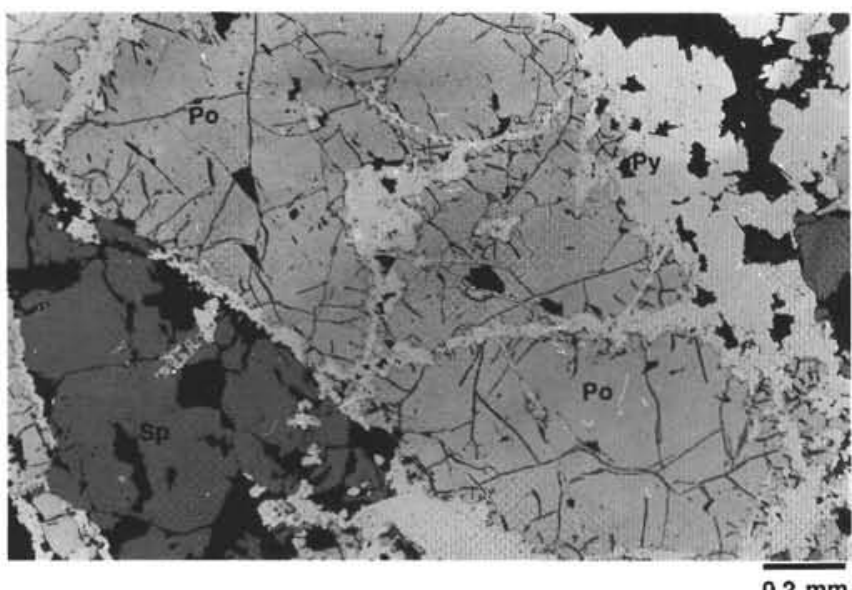

Figure 4. A large tabular crystal of pyrrhotite (Po), replaced and overgrown by pyrite (Py), with interstitial sphalerite (Sp). Photomicrograph in reflected light, Sample $139-856 \mathrm{H}-5 \mathrm{R}-1,52-53 \mathrm{~cm}$.

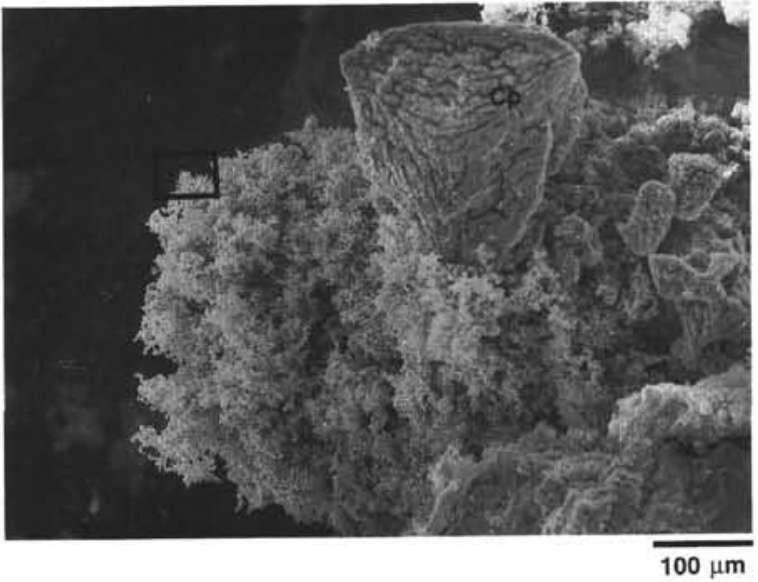

B
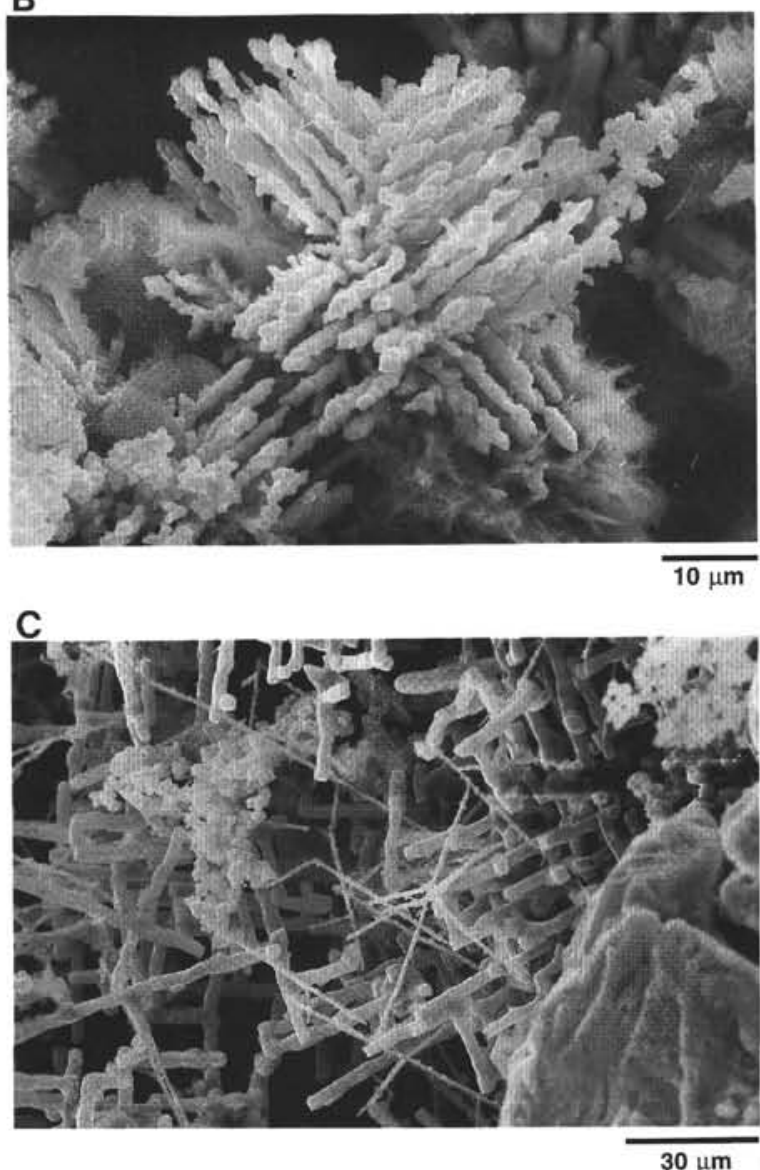

Figure 5. SEM photomicrographs of magnetite aggregates from cavities in massive sulfides. A. Mossy magnetite with a crystal of chalcopyrite (Cp), Sample $139-856 \mathrm{H}-5 \mathrm{R}-1,52-53 \mathrm{~cm}$; area in box is shown in (B). B. Skeletal magnetite crystal, shown enlarged from (A). C. Skeletal magnetite, Sample 139-856H-4R-1, 144-146 cm.

(Sample 139-856H-13R-1, 48-49 cm). Pyrite and magnetite cement the sediment or form network structures within it.

\section{Zone 4}

Below 75 mbsf, homogeneous fine-grained pyrrhotite defines zone 4 (Fig. 8). The pyrrhotite is mainly monoclinic, with traces of the hexagonal variety. Aggregates of anhedral grains and interpenetrating 


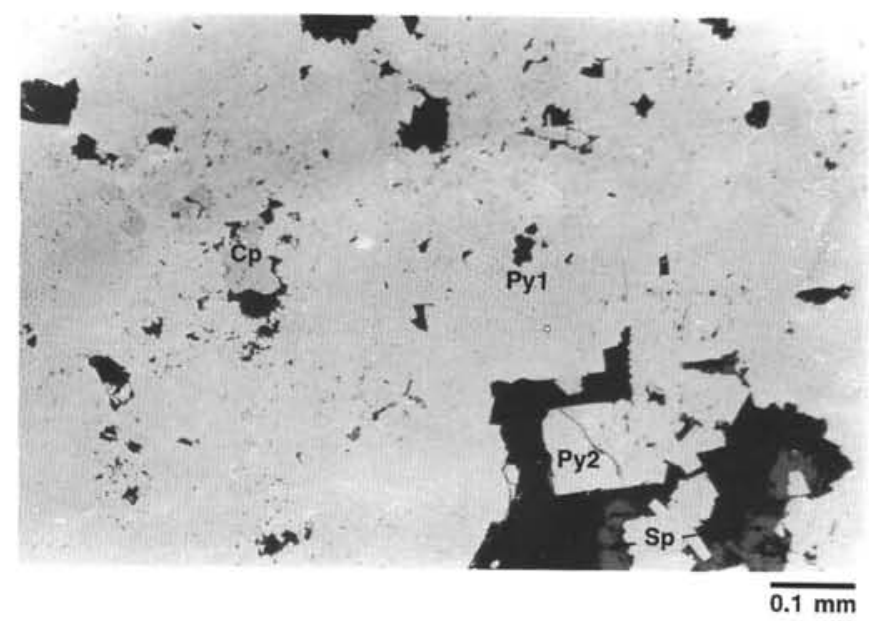

Figure 6. Recrystallized pyrite (Pyl), with chalcopyrite (Cp) and sphalerite (Sp), overgrown by euhedral Pyrite (Py2). Photomicrograph in reflected light, Sample 139-856H-10R-1, 13-15 cm.

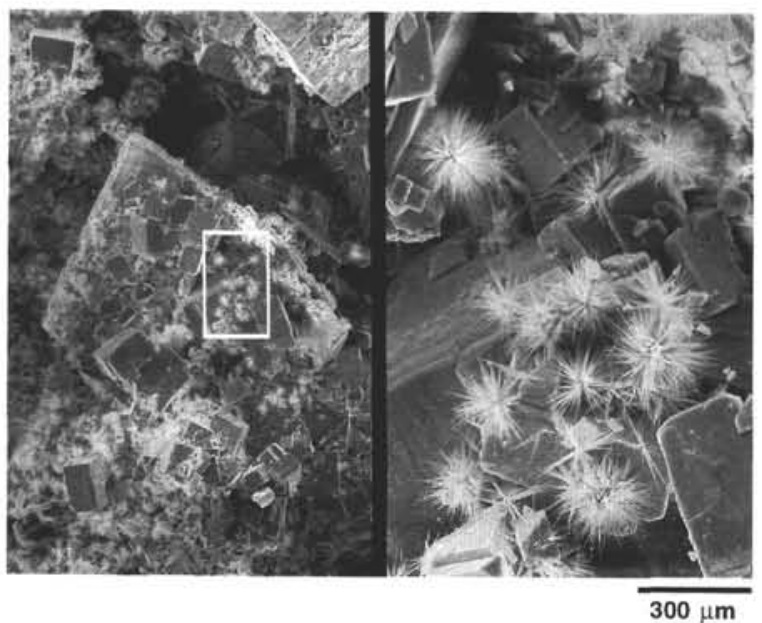

Figure 7. Overgrowth of a rhombic crystal of barite by cubic pyrite with hematite spherulites. SEM photomicrographs, Sample 139-856H-8R-1, 124 $126 \mathrm{~cm}$. The scale bar refers to the left, general view; box shows area of detail enlarged in right photomicrograph. Close-up (right) is enlarged 5.5 $\times$ ).

plates are most common. Pyrite forms rare euhedral crystals, up to 4 $\mathrm{mm}$ in size. Small ( 0.1 to $0.3 \mathrm{~mm})$ anhedral chalcopyrite grains are dispersed in the massive sulfide. Magnetite is scarce in the ore matrix, although it occurs locally, together with pyrite, in thin $(0.5 \mathrm{~mm})$ veinlets.

At the bottom of Hole $856 \mathrm{H}$, at about $90 \mathrm{mbsf}$, two pieces of brecciated sulfide were recovered. This sulfide differs in composition from that typical of zone 4 , in that pyrrhotite is partly recrystallized and replaced by pyrite containing fine-grained dispersed magnetite. Pyrite and minor marcasite also overgrow pyrrhotite. Chalcopyrite emulsion textures occur in coarse-grained, recrystallized pyrrhotite. Aragonite, the main gangue mineral, is dispersed in the sulfide and forms, along with calcite, dolomite, and chlorite, thin ramifying veinlets.

\section{Hole 856G}

The massive sulfides recovered from the second deepest hole (Hole $856 \mathrm{G}$, to $64 \mathrm{mbsf}$ ), differ mainly from those of Hole $856 \mathrm{H}$ by the almost complete absence of pyrrhotite. Evidence of the former existence of pyrrhotite is clearest in the upper part of the core, where thin boxwork textures of pyrite, overgrowing and partly replacing dissolved pyrrhotite crystals, can be seen. Two generations of pyrite

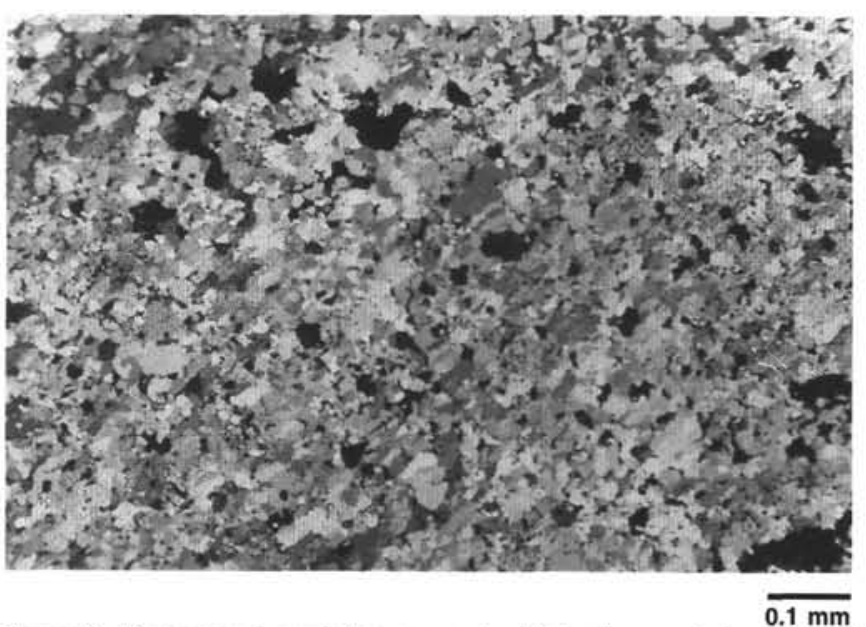

Figure 8. Fine-grained pyrrhotite aggregate. Photomicrograph in reflected light, Sample 139-856H-16R-1, 79-81 cm, under crossed nicols.

also are present, similar to those observed in Hole $856 \mathrm{H}$ (Fig. 9). Sulfides from the upper part of Hole $856 \mathrm{G}$ differ from the corresponding deposits of zone 1 in Hole $856 \mathrm{H}$ by containing skeletal magnetite crystals and small quantities (up to $5 \%$ ) of hematite. Morphologically similar magnetite is present in zone 2 of Hole $856 \mathrm{H}$, which is absent in Hole $856 \mathrm{G}$. Voids and pores between pyrite grains in the lower part of Hole $856 \mathrm{G}$ locally contain aggregates of spherulitic talc (Fig. 10). Sphalerite and magnetite are less evenly distributed in the upper part of Hole $856 \mathrm{G}$ than in zone 1 of Hole $856 \mathrm{H}$.

In spite of these differences, massive sulfides in the upper part of Hole $856 \mathrm{G}$ to about $40 \mathrm{mbsf}$ share the most characteristic feature of zone 1 in Hole $856 \mathrm{H}$, the presence of pyrite with tiny oriented magnetite intergrowths. This distinctive feature makes correlation between the two holes possible. Massive sulfides from the lower part of Hole 856G therefore clearly correlate with those of zone 3 in Hole $856 \mathrm{H}$.

\section{Holes 856C through 856F}

Massive sulfides from the shallower Holes $856 \mathrm{C}, 856 \mathrm{D}, 856 \mathrm{E}$, and $856 \mathrm{~F}$ were completely destroyed during drilling. On the whole they correspond to the upper part of zone 1 in Hole $856 \mathrm{H}$. Two sulfide varieties can be distinguished: silica-rich (more than $20 \% \mathrm{SiO}_{2}$ ), and relatively silica-poor. The silica-rich sulfides contain round, roseshaped pyrite aggregates that are generally similar to those in the sands of Hole $856 \mathrm{H}$, and are evenly dispersed in the siliceous matrix. The relatively silica-poor ores are similar to those in large clasts from the upper part of Hole $856 \mathrm{H}$, where pyrite replaces tabular crystals of pyrrhotite, forming boxwork textures.

Sulfide clasts, discovered in sediments from Hole $856 \mathrm{~B}$ between 18.4 and 24.2 mbsf, consist almost entirely of pyrite. Colloform, banded, and network structures are typical.

\section{ANALYTICAL RESULTS}

\section{Chemical Composition of the Cores}

Table 5 gives the results of bulk chemical analyses of sulfides from Site 856 , and Table 6 gives summary statistics, along with comparative data from other locations. The two elements that dominate the composition of the sulfide deposit, Fe and S, are distributed normally; other elements are distributed log-normally. In plotting element distribution with depth (Fig. 11), we have to consider drilling disturbances in the uppermost parts of the holes. The evident sorting of sulfides according to grain size along the length of cores may have influenced the distribution of elements. Therefore, in Figure 11 we plot average element concentrations between pairs of samples representing the bottom and 


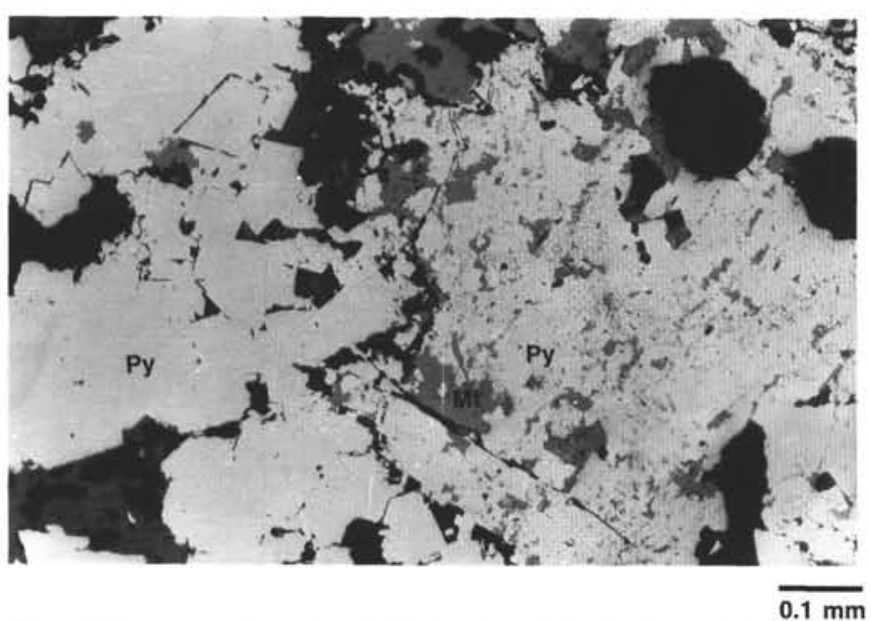

Figure 9 . Two generations of pyrite (Py): early anhedral pyrite, totally replacing pyrrhotite, with tiny magnetite (Mt) intergrowths (gray) on the right, and later subhedral pyrite, without magnetite, on the left. Photomicrograph in reflected light, Sample 139-856G-4R-1, 75-77 cm.

top parts of the disturbed cores, instead of data from each of these samples. Analytical values corresponding to the middle parts of the disturbed cores are plotted individually for each sample. We presume that this method of data presentation gives a more realistic trend of element distribution in massive sulfides that were disintegrated and sorted during the course of drilling.

The vertical profile of the deepest hole $(856 \mathrm{H})$ is characterized by a nonuniform distribution of most elements. Only several of the elements show general trends throughout the cored section. Concentrations of $\mathrm{Fe}, \mathrm{Co}$, and $\mathrm{Bi}$ tend to increase downhole; $\mathrm{Zn}, \mathrm{Mn}, \mathrm{Cd}, \mathrm{Sn}$, $\mathrm{Ta}$, and $\mathrm{Mg}$ increase uphole. $\mathrm{Zn}, \mathrm{Sn}$, and $\mathrm{Ta}$ concentrations increase abruptly in the uppermost part of the deposit. All of the other elements reveal a more complex behavior with depth in the sulfide deposit (Fig. 11, Table 5).

Changes in elemental concentrations from zone to zone, compared to average values, are described as follows.

Zone 1 is distinguished, along with relatively low Fe values in the sulfides, by variably high concentrations of many elements. In most samples throughout the zone, $\mathrm{Zn}, \mathrm{Cd}, \mathrm{Mn}, \mathrm{Se}, \mathrm{Sn}$, and $\mathrm{Al}$ contents are high. Some samples from the zone are rich in $\mathrm{Si}, \mathrm{Cr}, \mathrm{Cs}$, and $\mathrm{Ni}$, and several are significantly enriched in $\mathrm{V}$ and $\mathrm{Sc}$.

On the basis of the geochemical data, we divided zone 1 into two parts: the upper 1A and the lower 1B (Fig. 1). Many elements have distinctly different concentrations in the upper and lower parts of zone 1. In the upper part, to approximately $18 \mathrm{mbsf}, \mathrm{Fe}$ values are the lowest of the entire hole. Cu content is also low. Concentrations of $\mathrm{Zn}, \mathrm{Al}$, $\mathrm{Mg}, \mathrm{Si}, \mathrm{Au}, \mathrm{Ba}, \mathrm{Sb}, \mathrm{Sn}, \mathrm{Sr}, \mathrm{Ta}, \mathrm{Tl}, \mathrm{La}, \mathrm{Sm}$, and $\mathrm{Tb}$ are at a maximum here. Ag, As, Mn, Mo, and Ni concentrations are highly variable, but in individual samples they also reach maximum values for the entire hole. The lower part of zone 1 is marked by increased concentrations of $\mathrm{Cu}$ and $\mathrm{Se}$ and low $\mathrm{Au}, \mathrm{As}$, and $\mathrm{Sb}$. The peak in $\mathrm{Cu}$ concentration in the lower part of zone 1 is based on only three analyses (Fig. 11), but its existence is confirmed by the results of study aboard ship (Shipboard Scientific Party, 1992). Ca and Mg are enriched, due to the abundance of dolomite.

Zone 2 is characterized by relatively high Fe concentrations. $\mathrm{Cu}$ is low, and $\mathrm{Zn}$ is enriched in one sample from the upper part of the zone. Also relatively high in most samples are $\mathrm{Mn}$ and $\mathrm{Se}$, whereas $\mathrm{Pb}, \mathrm{Bi}$, $\mathrm{Co}, \mathrm{Ge}, \mathrm{Sn}$, and $\mathrm{U}$ contents are low compared to the average values for the deposit. Of the main gangue mineral elements, $\mathrm{Al}$ and $\mathrm{Mg}$ concentrations are higher than those in lower zone 3 due to the presence of chlorite.

Zone 3, which is dominated by pyrite, contains more $\mathrm{S}$ than any other zone. Its most characteristic features are very high concentra-

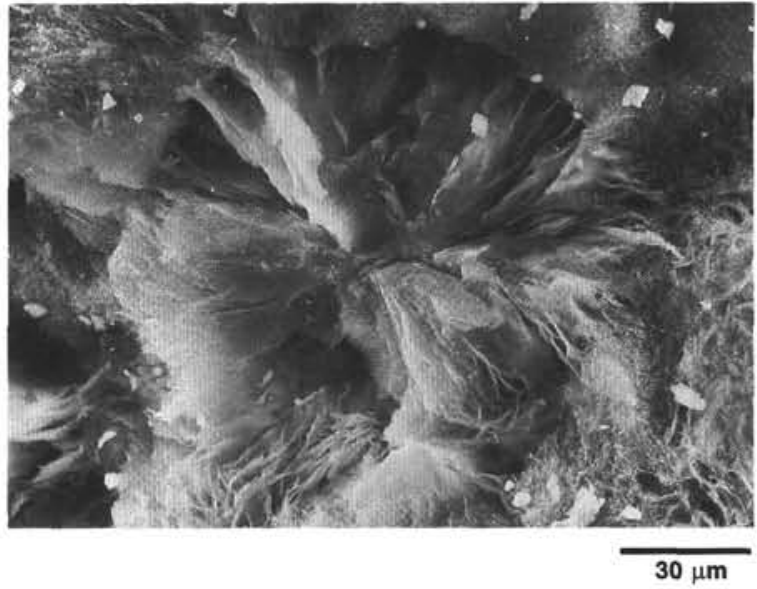

Figure 10. Talc spherulites from a cavity in massive sulfides. SEM photomicrograph, Sample 139-856G-6R-3, 95-97 cm.

tions of $\mathrm{Pb}, \mathrm{As}, \mathrm{Sb}, \mathrm{Ge}$, and $\mathrm{Tl}$ relative to those in the adjacent zone 2 and especially in zone 4. Concentrations of $\mathrm{Pb}$ and $\mathrm{Ge}$ are maxima for the entire hole. Co content increases downward within zone 3 . Au shows relatively high, though variable, concentrations compared to adjacent zones. All gangue mineral elements are low, except for enrichment of $\mathrm{Si}$ and $\mathrm{Mg}$ in the lowermost sample, which contains significant amounts of talc, and of $\mathrm{Ba}$ in the uppermost sample. At the lower boundary of zone $3, \mathrm{Sb}, \mathrm{As}, \mathrm{Ge}$, and $\mathrm{Tl}$ concentrations decrease abruptly.

Zone 4 is characterized by relatively low $\mathrm{S}$ and high $\mathrm{Fe}$ contents, owing to the dominance of pyrrhotite. Of the other elements, only $\mathrm{Cu}$, $\mathrm{Co}$, and $\mathrm{Bi}$ show high concentrations. $\mathrm{As}, \mathrm{Au}, \mathrm{Sb}, \mathrm{Ag}, \mathrm{Hg}$, and $\mathrm{Pb}$ values are low. The concentrations of all gangue mineral elements except $\mathrm{Al}$ are also low.

Not all features of the element distribution in Hole $856 \mathrm{G}$ are repeated in Hole $856 \mathrm{H}$. Although enrichment of the upper cores in $\mathrm{Ba}$, $\mathrm{As}, \mathrm{Au}, \mathrm{Mn}, \mathrm{Sb}, \mathrm{Se}, \mathrm{Sn}$, and Ta relative to the rest of the cores is evident (Fig. 11), no enrichment in $\mathrm{Zn}, \mathrm{Cd}, \mathrm{Si}$, and $\mathrm{Al}$ can be seen. This may be attributed to the aforementioned uneven distribution of sphalerite, as well as that of the gangue minerals, in the upper part of Hole $856 \mathrm{G}$. Element concentrations in the shallower Holes $856 \mathrm{C}$, $856 \mathrm{D}, 856 \mathrm{E}$, and $856 \mathrm{~F}$ also display maximum enrichment of the uppermost part of the deposit (corresponding to subzone 1A) in $\mathrm{Zn}$ and most of the minor elements.

Based on the average data of Davis et al. (1987) and Goodfellow and Blaise (1988), the surficial part of the same deposit that was sampled before drilling by conventional methods (Table 6) corresponds in chemical composition to that shown by the uppermost part of the cores (subzone $1 \mathrm{~A}$ ).

\section{REE Distribution}

Figure 12 shows chondrite-normalized patterns for rare earth elements (REE), averaged for each of the four compositional zones recognized in Hole $856 \mathrm{H}$. For comparison, similar patterns for massive sulfides from of the East Pacific Rise (EPR) and Mid-Atlantic Ridge (MAR), based on previous data of the authors (Krasnov et al., 1992), are also shown. In the upper part of the sulfide deposit, in zones 1 and 2, light rare earth elements (LREE) and intermediate REEs are enriched slightly over heavy rare earth elements (HREE). There are no Eu anomalies. The average Eu/Sm ratio is 0.95 . Lower in Hole $856 \mathrm{H}$, in pyrite ores of zone 3, abundances of LREEs do not exceed those of HREEs, and there is a well-pronounced positive Eu anomaly. The average Eu/Sm ratio is 1.72 . Pyrrhotite-rich massive sulfide in the lowermost part of Hole $856 \mathrm{H}$ (zone 4) also lacks a Eu anomaly. $\mathrm{The} \mathrm{Eu} / \mathrm{Sm}$ ratio is 0.78 . 
Table 5. Element concentrations in bulk sulfïde samples from Site 856.

\begin{tabular}{|c|c|c|c|c|c|c|c|c|c|c|c|c|c|c|c|c|c|}
\hline $\begin{array}{l}\text { Core, section, } \\
\text { interval }(\mathrm{cm})\end{array}$ & $\begin{array}{l}\text { Depth } \\
\text { (mbsf) }\end{array}$ & Description & $\begin{array}{l}\mathrm{Fe} \\
(\%)\end{array}$ & $\begin{array}{c}\mathrm{Zn} \\
(\mathrm{ppm})\end{array}$ & $\underset{(\mathrm{ppm})}{\mathrm{Cu}}$ & $\begin{array}{l}\mathrm{CaO} \\
(\mathrm{ppm})\end{array}$ & $\begin{array}{l}\mathrm{MgO} \\
\text { (ppm) }\end{array}$ & $\begin{array}{c}\mathrm{Mn} \\
(\mathrm{ppm})\end{array}$ & $\underset{(\%)}{S}$ & $\begin{array}{l}\mathrm{SiO}_{2} \\
(\%)\end{array}$ & $\begin{array}{l}\mathrm{Al}_{2} \mathrm{O}_{3} \\
(\%)\end{array}$ & $\underset{(\mathrm{ppm})}{\mathrm{Cd}}$ & $\begin{array}{c}\mathrm{Au} \\
(\mathrm{ppb})\end{array}$ & $\begin{array}{c}\mathrm{Ag} \\
(\mathrm{ppm})\end{array}$ & $\begin{array}{c}\text { As } \\
\text { (ppm) }\end{array}$ & $\begin{array}{c}\mathrm{Sb} \\
(\mathrm{ppm})\end{array}$ & $\begin{array}{c}\mathrm{Co} \\
(\mathrm{ppm})\end{array}$ \\
\hline $\begin{array}{l}\text { 139-856B- } \\
3 \mathrm{H}-5,110-113\end{array}$ & 18.40 & Sulfide clasts from sediments & 45.55 & 0.76 & 0.12 & 0.13 & 0.53 & 70 & 50.94 & 1.12 & 0.16 & 27 & 170 & 5.0 & 180 & 13.0 & 6.0 \\
\hline $\begin{array}{l}139-856 \mathrm{C}- \\
1 \mathrm{H}-1,48-50\end{array}$ & 0.48 & Sulfide clasts & 41.48 & 5.60 & 0.50 & 0.10 & 0.13 & 460 & 39.68 & 3.80 & 0.62 & 67 & 145 & 2.0 & 33 & 4.0 & 2.1 \\
\hline $\begin{array}{l}139-856 \mathrm{D}- \\
1 \mathrm{H}-1,99-102 \\
1 \mathrm{H}-2,64-67 \\
1 \mathrm{H}-4,62-64 \\
1 \mathrm{H}-5,113-116\end{array}$ & $\begin{array}{l}0.99 \\
2.14 \\
5.12 \\
7.13\end{array}$ & $\begin{array}{l}\text { Sulfide-silicate clasts } \\
\text { Sulfide-silicate clasts } \\
\text { Sulfide-silica clasts } \\
\text { Sulfide-silicate clasts }\end{array}$ & $\begin{array}{l}23.98 \\
23.63 \\
16.28 \\
24.32\end{array}$ & $\begin{array}{l}4.05 \\
3.53 \\
3.11 \\
3.32\end{array}$ & $\begin{array}{l}0.21 \\
0.27 \\
0.16 \\
0.25\end{array}$ & $\begin{array}{l}0.09 \\
0.11 \\
0.10 \\
0.11\end{array}$ & $\begin{array}{r}10.05 \\
5.91 \\
4.07 \\
7.01\end{array}$ & $\begin{array}{l}330 \\
220 \\
120 \\
180\end{array}$ & $\begin{array}{l}28.13 \\
27.87 \\
18.70 \\
27.69\end{array}$ & $\begin{array}{l}24.00 \\
31.20 \\
47.80 \\
30.50\end{array}$ & $\begin{array}{r}0.36 \\
0.74 \\
<0.01 \\
0.26\end{array}$ & $\begin{array}{l}64 \\
54 \\
30 \\
44\end{array}$ & $\begin{array}{r}160 \\
86 \\
15 \\
175\end{array}$ & $\begin{array}{r}2.0 \\
3.0 \\
<1.0 \\
<1.0\end{array}$ & $\begin{array}{r}40 \\
30 \\
5 \\
28\end{array}$ & $\begin{array}{r}17.0 \\
13.0 \\
2.0 \\
3.2\end{array}$ & $\begin{array}{l}4.0 \\
7.5 \\
3.6 \\
8.0\end{array}$ \\
\hline $\begin{array}{l}139-856 \mathrm{E}- \\
1 \mathrm{H}-1,106-108 \\
1 \mathrm{H}-2,84-86\end{array}$ & $\begin{array}{l}1.06 \\
2.34\end{array}$ & $\begin{array}{l}\text { Sulfide clasts } \\
\text { Sulfide clasts }\end{array}$ & $\begin{array}{l}32.20 \\
44.80\end{array}$ & $\begin{array}{r}17.40 \\
1.11\end{array}$ & $\begin{array}{l}0.91 \\
0.18\end{array}$ & $\begin{array}{l}0.15 \\
0.15\end{array}$ & $\begin{array}{l}0.17 \\
0.21\end{array}$ & $\begin{array}{r}1000 \\
730\end{array}$ & $\begin{array}{l}37.61 \\
50.21\end{array}$ & $\begin{array}{l}0.06 \\
0.36\end{array}$ & $\begin{array}{r}0.04 \\
\text { n.a. }\end{array}$ & $\begin{array}{r}954 \\
34\end{array}$ & $\begin{array}{r}\text { n.a. } \\
82\end{array}$ & $\begin{array}{l}\text { n.a. } \\
5.0\end{array}$ & $\begin{array}{r}\text { n.a. } \\
52\end{array}$ & $\begin{array}{l}\text { n.a. } \\
6.8\end{array}$ & $\begin{array}{r}\text { n.a. } \\
1.0\end{array}$ \\
\hline $\begin{array}{l}\text { 139-856F- } \\
2 \text { X-CC, } 1-3 \\
2 \text { X-CC, } 32-34\end{array}$ & $\begin{array}{l}11.71 \\
12.02\end{array}$ & $\begin{array}{l}\text { Sulfide-silica clasts } \\
\text { Sulfide clasts }\end{array}$ & $\begin{array}{l}17.50 \\
34.30\end{array}$ & $\begin{array}{l}1.09 \\
1.15\end{array}$ & $\begin{array}{l}0.10 \\
0.22\end{array}$ & $\begin{array}{l}0.20 \\
1.15\end{array}$ & $\begin{array}{l}0.72 \\
7.35\end{array}$ & $\begin{array}{r}30 \\
330\end{array}$ & $\begin{array}{l}21.20 \\
28.20\end{array}$ & $\begin{array}{r}55.16 \\
9.44\end{array}$ & $\begin{array}{l}0.10 \\
0.14\end{array}$ & $\begin{array}{l}30 \\
37\end{array}$ & $\begin{array}{l}110 \\
108\end{array}$ & $\begin{array}{l}2.0 \\
4.0\end{array}$ & $\begin{array}{l}34 \\
<1\end{array}$ & $\begin{array}{l}3.6 \\
0.6\end{array}$ & $\begin{array}{l}3.2 \\
9.0\end{array}$ \\
\hline $\begin{array}{l}139-856 \mathrm{G}- \\
\text { IR-1, 145-147 } \\
\text { IR-4, 42--44 } \\
2 \mathrm{R}-1,67-69 \\
2 \mathrm{R}-3,29-31 \\
2 \mathrm{R}-5,64-66 \\
3 \mathrm{R}-1,61-64 \\
4 \mathrm{R}-1,49-51 \\
4 \mathrm{R}-1,75-77 \\
5 \mathrm{R}-1,47-49 \\
6 \mathrm{R}-2,101-103 \\
6 \mathrm{R}-3,95-97 \\
7 \mathrm{R}-1,38-40 \\
7 \mathrm{R}-4,67-69\end{array}$ & $\begin{array}{r}1.45 \\
4.92 \\
9.27 \\
11.89 \\
15.24 \\
18.21 \\
27.49 \\
27.75 \\
37.17 \\
48.81 \\
50.25 \\
56.18 \\
60.77\end{array}$ & $\begin{array}{l}\text { Sulfide clasts } \\
\text { Sulfide sand } \\
\text { Sulfide-silicate clasts } \\
\text { Sulfide clasts } \\
\text { Sulfide sand } \\
\text { Massive sulfide } \\
\text { Massive sulfide } \\
\text { Massive sulfide } \\
\text { Massive sulfide } \\
\text { Porous massive sulfide } \\
\text { Porous massive sulfide } \\
\text { Porous massive sulfide } \\
\text { Porous massive sulfide }\end{array}$ & $\begin{array}{l}43.40 \\
41.93 \\
19.78 \\
41.50 \\
23.80 \\
45.55 \\
42.70 \\
46.20 \\
36.40 \\
43.40 \\
44.80 \\
42.70 \\
43.40\end{array}$ & $\begin{array}{l}0.10 \\
0.30 \\
0.92 \\
0.09 \\
0.82 \\
0.50 \\
1.53 \\
0.29 \\
0.06 \\
1.08 \\
0.04 \\
0.08 \\
0.08\end{array}$ & $\begin{array}{l}0.48 \\
0.40 \\
0.23 \\
0.35 \\
0.23 \\
0.71 \\
0.74 \\
0.29 \\
0.22 \\
0.06 \\
0.02 \\
0.90 \\
0.41\end{array}$ & $\begin{array}{l}0.09 \\
0.09 \\
0.22 \\
0.90 \\
0.25 \\
0.35 \\
0.25 \\
0.35 \\
0.20 \\
0.20 \\
0.20 \\
0.20 \\
0.10\end{array}$ & $\begin{array}{r}0.24 \\
0.55 \\
11.98 \\
0.22 \\
9.88 \\
2.90 \\
2.27 \\
3.25 \\
9.20 \\
1.12 \\
1.27 \\
2.50 \\
1.97\end{array}$ & $\begin{array}{r}680 \\
630 \\
530 \\
1600 \\
530 \\
540 \\
130 \\
290 \\
90 \\
170 \\
50 \\
60 \\
<20\end{array}$ & $\begin{array}{l}50.61 \\
50.35 \\
23.83 \\
52.63 \\
28.90 \\
35.11 \\
40.57 \\
35.40 \\
35.07 \\
50.49 \\
51.84 \\
50.09 \\
49.11\end{array}$ & $\begin{array}{r}1.00 \\
1.80 \\
32.40 \\
0.40 \\
4.60 \\
3.32 \\
5.26 \\
1.80 \\
7.70 \\
2.38 \\
0.78 \\
3.10 \\
2.64\end{array}$ & $\begin{array}{r}0.42 \\
0.44 \\
<0.01 \\
0.38 \\
0.26 \\
0.26 \\
0.06 \\
0.14 \\
0.04 \\
0.12 \\
0.04 \\
0.16 \\
0.16\end{array}$ & $\begin{array}{r}<10 \\
13 \\
15 \\
<10 \\
19 \\
<10 \\
37 \\
<10 \\
<10 \\
30 \\
<10 \\
13 \\
<10\end{array}$ & $\begin{array}{r}44 \\
120 \\
140 \\
290 \\
260 \\
23 \\
60 \\
35 \\
12 \\
50 \\
56 \\
44 \\
64\end{array}$ & $\begin{array}{r}7.0 \\
8.0 \\
4.0 \\
18.0 \\
3.0 \\
3.9 \\
4.3 \\
1.5 \\
1.0 \\
2.6 \\
3.0 \\
5.5 \\
4.7\end{array}$ & $\begin{array}{r}110 \\
98 \\
140 \\
35 \\
165 \\
7 \\
48 \\
9 \\
93 \\
55 \\
38 \\
60 \\
140\end{array}$ & $\begin{array}{r}13.0 \\
16.0 \\
12.0 \\
11.0 \\
13.0 \\
1.7 \\
3.2 \\
0.8 \\
0.3 \\
0.5 \\
0.7 \\
1.4 \\
1.6\end{array}$ & $\begin{array}{r}14.0 \\
22.0 \\
10.0 \\
3.4 \\
5.8 \\
9.2 \\
8.6 \\
24.0 \\
6.6 \\
2.1 \\
3.8 \\
83.0 \\
23.0\end{array}$ \\
\hline $39-856 \mathrm{H}-$ & & & & & & & & & & & & & & & & & \\
\hline $1 \mathrm{R}-1,108-110$ & 1.08 & Sulfide-silicate clasts & 31.70 & 0.65 & 0.41 & 0.66 & 1.04 & 2000 & 28.83 & 14.40 & 20.00 & 46 & 110 & 3.0 & 280 & 13.0 & 20.0 \\
\hline IR $-2,4-7$ & 1.54 & Sulfide sand & 28.60 & 2.31 & 0.18 & 0.64 & 7.18 & 350 & 34.30 & 18.90 & $<0.01$ & 32 & 156 & 4.0 & 50 & 7.8 & 5.4 \\
\hline IR-3, 59-62 & 3.59 & Sulfide sand & 29.57 & 2.04 & 0.16 & 0.41 & 6.41 & 330 & 37.22 & 17.50 & 0.2 & 27 & 130 & 3.0 & 74 & 8.6 & 6.5 \\
\hline IR-CC. 3-5 & 3.96 & Sulfide clasts & 35.52 & 10.00 & 0.40 & 0.10 & 0.73 & 1400 & 45.90 & 1.6 & 0. & 71 & 250 & 10.0 & 66 & 13.0 & 5.7 \\
\hline $2 \mathrm{R}-1,8-10$ & 13.58 & Massive sulfide & 29.40 & 4.62 & 0.23 & 4.20 & 9.40 & 610 & 24.52 & 8.6 & 0.3 & 98 & 8 & $<1.0$ & $<1$ & 0.7 & 3.7 \\
\hline $3 R-1,34-37$ & 22.44 & Massive sulfide & 39.90 & 2.91 & 0.66 & 4.50 & 4.20 & 150 & 31.36 & 1.6 & 0. & 88 & 13 & 1.7 & 3 & 0.6 & 8.9 \\
\hline $3 \mathrm{R}-2,67-70$ & 23.93 & Massi & 39.20 & 1.51 & 1.48 & 4.25 & 6.20 & 210 & 28.15 & 4.2 & 1.0 & 4 & 42 & 3. & $<1$ & 0.7 & 54.0 \\
\hline $3 R-3,14-16$ & 24.85 & Massive sulfide & 43.75 & 3.21 & 0.65 & 1.25 & 2.23 & 150 & 35.66 & 1.6 & 0. & 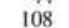 & 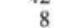 & 5. & 7 & 0.4 & 24.0 \\
\hline $4 \mathrm{R}-1,18-20$ & 26.78 & Sulfide in altered sediment & 38.50 & 0.77 & 0.28 & 3.60 & 6.20 & 400 & 28.6 & 7.2 & 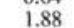 & 2 & 22 & 1. & 4 & 0.7 & 14.0 \\
\hline $4 \mathrm{R}-2,144-146$ & 29.54 & $\begin{array}{l}\text { Massive sulfide } \\
\text { Selin }\end{array}$ & 58.10 & 0.54 & 0.34 & 0.20 & 0.13 & 30 & 35.85 & 0.10 & 0.16 & 17 & 22 & 2.6 & $<1$ & 0.1 & 84.0 \\
\hline $5 R-1,52-53$ & 32.92 & Massive sulfide & 49.35 & 4.28 & 0.21 & 0.50 & 0.62 & 260 & 38.55 & 0.62 & 0.16 & 129 & 11 & 3.2 & 6 & 0.5 & 7.5 \\
\hline $6 \mathrm{R}-1,24-26$ & 37.64 & Massive sulfide & 46.55 & 0.27 & 0.13 & 0.25 & 2.92 & 260 & 33.14 & 8.12 & 0.36 & 20 & 32 & 1.0 & 74 & 5.5 & 14.0 \\
\hline $7 \mathrm{R}-1,80-82$ & 43.90 & Massive sulfide & 38.85 & 0.12 & 0.10 & 5.55 & 3.77 & 230 & 39.84 & 1.80 & 0.12 & $<10$ & 52 & 2.8 & 12 & 0.5 & 13.0 \\
\hline $8 \mathrm{R}-1,124-126$ & 49.24 & Porous massive sulfide & 41.30 & 0.42 & 0.31 & 0.25 & 1.41 & 50 & 47.68 & 2.70 & 0.0 & 17 & 86 & 3.9 & 160 & 5.5 & 88.0 \\
\hline $9 \mathrm{R}-1,80-82$ & 53.30 & Porous massive sulfide & 45.50 & 0.06 & 0.74 & 0.10 & 0.54 & 20 & 52.56 & 0.70 & 0. & $<1$ & 24 & 2.8 & 53 & 3.9 & 40.0 \\
\hline $10 \mathrm{R}-1,13-15$ & 57.13 & Porous massive sulfide & 44.45 & 0.25 & 0.58 & 0.10 & 0.17 & 50 & 51.14 & 1.50 & 0.08 & $<10$ & 36 & 3.9 & 67 & 3.6 & 56.0 \\
\hline IIR-1, 49-51 & 61.79 & Porous massive sulfide & 44.80 & 0.08 & 0.40 & 0.10 & 1.52 & n.a. & 52.97 & 1.68 & 0.04 & $<1$ & 99 & 3.4 & 94 & 3.7 & 130.0 \\
\hline $13 \mathrm{R}-1,48-49$ & 71.38 & Sulfide-talcose aggregate & 33.60 & 0.04 & 0.91 & 0.20 & 10.00 & 140 & 30.81 & 20.06 & 0.02 & $<10$ & 36 & 2.5 & 80 & 4.1 & 380.0 \\
\hline $14 R-1,4-6$ & 75.74 & Massive sulfide & 52.15 & 0.41 & 0.91 & 0.10 & 0.83 & 20 & 35.12 & 0.84 & 0.08 & $<1$ & 22 & 2.7 & 2 & 0.2 & 210.0 \\
\hline $15 \mathrm{R}-1,60-62$ & 81.10 & Massive sulfide & 52.85 & 0.23 & 0.43 & 0.75 & 1.95 & 90 & 35.18 & 2.14 & 0.58 & $<10$ & 7 & 2.0 & $<1$ & 0.2 & 60.0 \\
\hline 16R-1.79-81 & 85.99 & Massive sulfide & 55.30 & 0.09 & 1.74 & 0.1 & 0.29 & $<20$ & 37.41 & 0.30 & 0.12 & $<10$ & 14 & 2.7 & $<1$ & 0.2 & 190.0 \\
\hline $17 \mathrm{R}-1,35-36$ & 90.45 & Sulfide breccia & 29.40 & 0.04 & 0.21 & 5.00 & 2.87 & 190 & 31.44 & 4.24 & 1.24 & $<10$ & 12 & 1.6 & 2 & 0.3 & 100.0 \\
\hline
\end{tabular}

\section{Element Associations in Sulfides}

Linear correlation analysis was used to study the relations among elements in massive sulfide samples. The results are given in Table 7. Figure $13 \mathrm{~A}$ shows the main positive correlations. For comparison, a similar scheme is also given, based on geochemical data (Krasnov et al., 1992) for samples of massive sulfides from several sites at sediment-free mid-oceanic ridges (Fig. 13B).

Massive sulfides from the studied cores show rather weak correlations among the elements. The main ore-forming metals have few significant correlations. Fe correlates only with S (group 1, Fig. 13A) and slightly with $\mathrm{Cu}$. Cu forms a separate group (2) with two strongly correlated metals that enrich the pyrrhotite ores of the lowermost part of Hole $856 \mathrm{H}$ (zone 4): Co and Bi.

$\mathrm{Zn}$ shows the strongest correlations with $\mathrm{Cd}$ and $\mathrm{Pb}$ (group 3), typical of all oceanic massive sulfides. $\mathrm{Zn}$, however, differs in its behavior in the sulfides at Site 856 relative to those of sediment-free ridges because it is not correlated with $\mathrm{Ag}$ nor with elements such as $\mathrm{Ba}$ and $\mathrm{As}$ that are characteristic of low-temperature surficial facies of oceanic sulfide bodies.

$\mathrm{Ba}$ and $\mathrm{Sr}$ tend to form their own small element group (4). This group is associated through the usual $\mathrm{Ba}-\mathrm{Sb}$ correlation with the most dense association of elements (group 5), including Sb, Sn, Mn, Ag, $\mathrm{Au}, \mathrm{As}, \mathrm{Mo}$, and Tl. All of these elements are enriched in the surficial part of the deposit. They are, however, neither directly related to zinc sulfides nor to the main gangue minerals.

Three additional geochemical groups $(6,7$, and 8$)$ are associated with different gangue minerals that are also enriched in the upper part of the ore body. The Al-related group (6), including most of the lithophile elements, is the largest and most tightly associated through the $\mathrm{Mn}-\mathrm{Al}$ correlation with group $5 . \mathrm{Si}$ (with $\mathrm{Ta}$ and $\mathrm{Hg}$ ) and $\mathrm{Ca}$ (with V) form separate groups (7 and 8 , respectively).

\section{MINERAL CHEMISTRY}

\section{Microprobe Analyses}

Results of microprobe analyses of minerals are shown in Tables 8 through 10 . Iron concentrations in sphalerites (Table 8) are mostly in the range of 11 to $16 \mathrm{wt} \% \mathrm{Fe}$. The only sphalerite grain analyzed from almost pure pyritic massive sulfide of zone 3 (Sample 139-856G$6 \mathrm{R}-2,101-103 \mathrm{~cm}$ ) has a much lower $\mathrm{Fe}$ content $(4.8 \mathrm{wt} \%)$ than sphalerites from the other zones. Among the analyzed pyrites (Table 9 ), varieties from magnetite-bearing zones are mostly $\mathrm{Fe}$-deficient in comparison to their theoretical compositions. Iron concentrations are 
Table 5 (continued).

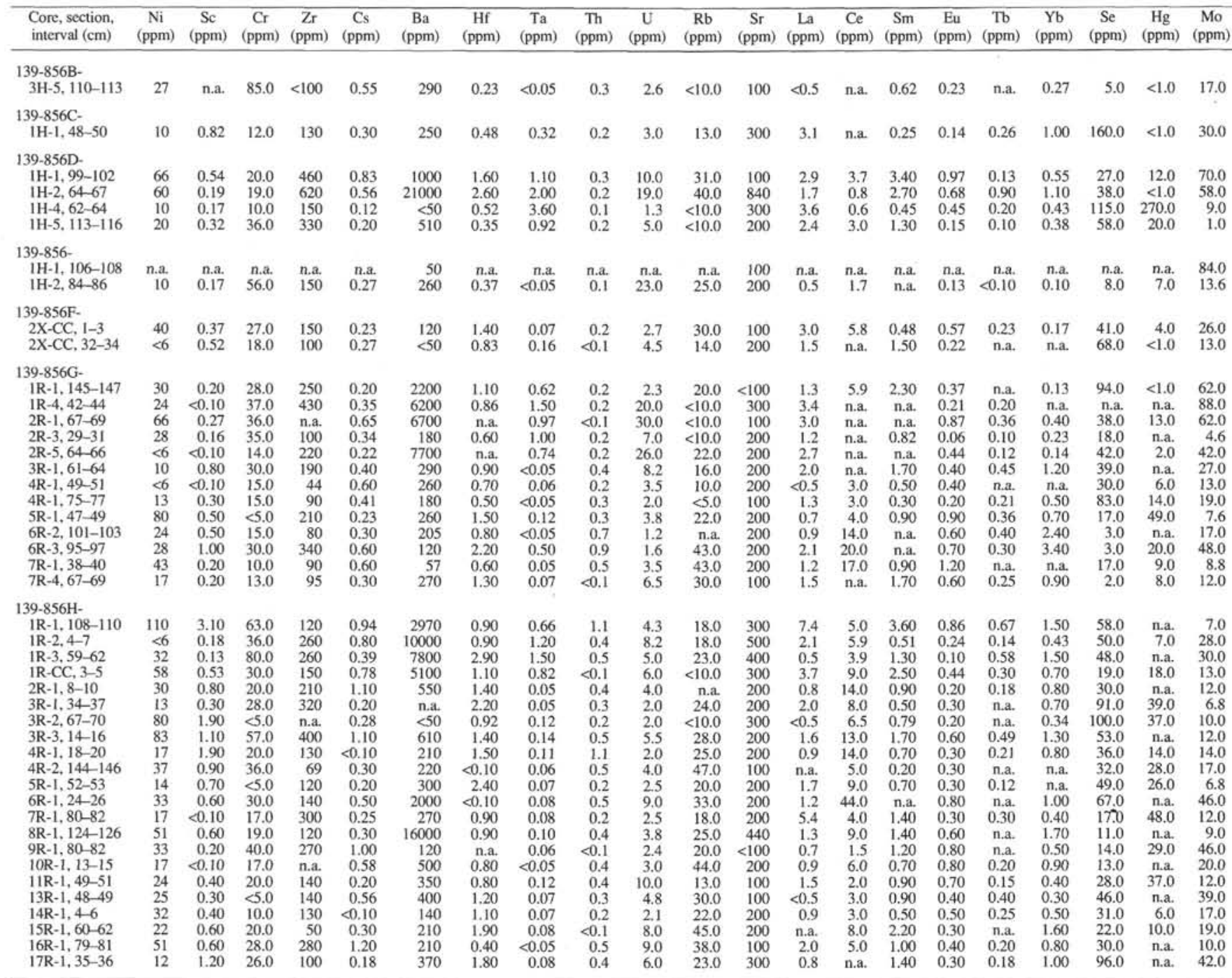

higher in the cores of pyrite grains than in the rims of the same grains. $\mathrm{Cu}-\mathrm{Fe}$ sulfides are deficient in $\mathrm{Cu}$ (Table 10).

\section{Neutron Activation Analyses}

Table 11 presents the results of neutron activation analyses of sulfide minerals hand-picked from samples of massive sulfide. Comparative data on the chemical composition of minerals from oceanic sulfide deposits of other regions (EPR and MAR) are also included. It was possible to separate only pyrite without visible contamination from most of the samples. We also managed to pick sphalerite and pyrrhotite out of one of the samples from zone 2 in Hole $856 \mathrm{H}$.

Sphalerite is richer in minor elements relative to other minerals of the sulfide deposit. In Sample $139-856 \mathrm{H}-5 \mathrm{R}-1,52-53 \mathrm{~cm}$, from which different minerals were analyzed, most of the elements reach their maximum concentrations in sphalerite. One exception is Co, which is preferentially enriched in pyrrhotite. This is consistent with Co enrichment in bulk samples of pyrrhotitic sulfide from zone 4 in Hole $856 \mathrm{H}$. Also enriched in pyrrhotite, compared to other minerals, are $\mathrm{Cs}, \mathrm{Se}, \mathrm{Hg}$, and $\mathrm{Yb}$. Pyrite is characterized by maximum concentrations of $U$ and $S m$, relative to other sulfides.

\section{DISCUSSION}

\section{Comparison of Chemical Composition with Other Seafloor Sulfide Deposits}

The average chemical data from Site 856 cannot be directly compared with data for other oceanic massive sulfide deposits that were sampled only from the surface. The sharp downward decrease in concentrations of most elements in the Middle Valley cores is the main reason that the averages for $\mathrm{Zn}, \mathrm{Cu}$, and most of the minor elements are low (Table 6). Most of the gangue-related elements have the same range of concentrations as those of other seafloor deposits. $\mathrm{Mg}$ and $\mathrm{Ca}$ are higher than in most of the deposits, however. Guaymas Basin in the Gulf of California, where massive sulfides also overlie sedimentary cover, is the only site for which the published data on these elements are comparable to those for the cores from Middle Valley.

The absence of any significant enrichment of the Middle Valley deposit in elements common to oceanic massive sulfides from sedimentary environments, such as $\mathrm{Pb}, \mathrm{As}$, and $\mathrm{Sb}$, is especially noteworthy. This absence of sediment-derived elements holds true even for the surficial part of the deposit, where element concentrations increase. 
Table 5 (continued).

\begin{tabular}{|c|c|c|c|c|c|c|c|c|}
\hline $\begin{array}{l}\text { Core, section, } \\
\text { interval }(\mathrm{cm})\end{array}$ & $\begin{array}{c}\mathrm{Ti} \\
(\mathrm{ppm})\end{array}$ & $\begin{array}{c}\mathrm{Pb} \\
(\mathrm{ppm})\end{array}$ & $\begin{array}{c}\mathrm{Sn} \\
(\mathrm{ppm})\end{array}$ & $\begin{array}{c}\mathrm{Bi} \\
(\mathrm{ppm})\end{array}$ & $\begin{array}{c}\mathrm{Ge} \\
(\mathrm{ppm})\end{array}$ & $\begin{array}{c}\mathrm{T} \\
(\mathrm{ppm})\end{array}$ & $\underset{(\mathrm{ppm})}{\mathrm{V}}$ & $\underset{(\mathrm{ppm})}{\mathrm{Li}}$ \\
\hline $\begin{array}{l}\text { 139-856B- } \\
3 \mathrm{H}-5,110-113\end{array}$ & 22 & 120 & 20.0 & $<0.5$ & 15.0 & 5.1 & $<5$ & $<30$ \\
\hline $\begin{array}{l}139-856 \mathrm{C}- \\
\quad 1 \mathrm{H}-1,48-50\end{array}$ & 43 & 534 & 5.4 & 0.9 & $<1.0$ & 1.0 & $<5$ & $<30$ \\
\hline $\begin{array}{l}\text { 139-856D- } \\
1 \mathrm{H}-1,99-102 \\
1 \mathrm{H}-2,64-67 \\
1 \mathrm{H}-4,62-64 \\
1 \mathrm{H}-5,113-116\end{array}$ & $\begin{array}{r}12 \\
17 \\
34 \\
8\end{array}$ & $\begin{array}{r}132 \\
74 \\
34 \\
60\end{array}$ & $\begin{array}{r}53.0 \\
46.0 \\
14.0 \\
7.8\end{array}$ & $\begin{array}{l}1.2 \\
1.1 \\
1.1 \\
2.0\end{array}$ & $\begin{array}{r}4.0 \\
4.0 \\
<1.0 \\
<1.0\end{array}$ & $\begin{array}{l}3.1 \\
3.7 \\
1.6 \\
4.0\end{array}$ & $\begin{array}{l}<5 \\
<5 \\
<5 \\
<5\end{array}$ & $\begin{array}{r}40 \\
<30 \\
30 \\
40\end{array}$ \\
\hline $\begin{array}{l}139-856- \\
1 \mathrm{H}-1,106-108 \\
1 \mathrm{H}-2,84-86\end{array}$ & $\begin{array}{l}83 \\
22\end{array}$ & $\begin{array}{r}98 \\
170\end{array}$ & $\begin{array}{r}100.0 \\
27.0\end{array}$ & $\begin{array}{l}<0.5 \\
<0.5\end{array}$ & $\begin{array}{l}9.0 \\
9.0\end{array}$ & $\begin{array}{l}9.2 \\
5.5\end{array}$ & $\begin{array}{l}11 \\
14\end{array}$ & $\begin{array}{l}<30 \\
<30\end{array}$ \\
\hline $\begin{array}{l}\text { 139-856F- } \\
2 \mathrm{X}-\mathrm{CC}, 1-3 \\
2 \mathrm{X}-\mathrm{CC}, 32-34\end{array}$ & $\begin{array}{l}36 \\
42\end{array}$ & $\begin{array}{r}<10 \\
54\end{array}$ & $\begin{array}{r}15.0 \\
5.6\end{array}$ & $\begin{array}{l}0.7 \\
1.0\end{array}$ & $\begin{array}{l}1.0 \\
2.5\end{array}$ & $\begin{array}{l}3.0 \\
2.0\end{array}$ & $\begin{array}{l}<5 \\
<5\end{array}$ & $\begin{array}{l}<30 \\
<30\end{array}$ \\
\hline $\begin{array}{l}\text { 139-856G- } \\
\text { IR-1, 145-147 } \\
\text { IR-4, 42-44 } \\
\text { 2R-1,67-69 } \\
2 \mathrm{R}-3,29-31 \\
2 \mathrm{R}-5,64-66 \\
3 \mathrm{R}-1,61-64 \\
4 \mathrm{R}-1,49-51 \\
4 \mathrm{R}-1,75-77 \\
5 \mathrm{R}-1,47-49 \\
6 \mathrm{R}-2,101-103 \\
6 \mathrm{R}-3,95-97 \\
7 \mathrm{R}-1,38-40 \\
7 \mathrm{R}-4,67-69\end{array}$ & $\begin{array}{r}30 \\
16 \\
9 \\
<1 \\
11 \\
46 \\
44 \\
75 \\
350 \\
40 \\
44 \\
72 \\
180\end{array}$ & $\begin{array}{r}136 \\
210 \\
100 \\
20 \\
118 \\
66 \\
92 \\
61 \\
<10 \\
120 \\
75 \\
110 \\
130\end{array}$ & $\begin{array}{r}48.0 \\
28.0 \\
22.0 \\
45.0 \\
26.0 \\
12.0 \\
23.0 \\
6.0 \\
5.0 \\
5.8 \\
3.0 \\
5.0 \\
6.0\end{array}$ & $\begin{array}{r}1.5 \\
<0.5 \\
1.2 \\
<0.5 \\
1.6 \\
1.8 \\
2.2 \\
1.0 \\
0.5 \\
<0.5 \\
<0.5 \\
2.6 \\
2.2\end{array}$ & $\begin{array}{r}1.0 \\
<1.0 \\
3.0 \\
<1.0 \\
2.0 \\
3.4 \\
<1.0 \\
<1.0 \\
<1.0 \\
20.0 \\
8.2 \\
9.3 \\
10.0\end{array}$ & $\begin{array}{r}7.3 \\
4.9 \\
5.0 \\
4.0 \\
9.2 \\
2.2 \\
<1.0 \\
<1.0 \\
<1.0 \\
7.9 \\
14.0 \\
4.5 \\
4.4\end{array}$ & $\begin{array}{l}<5 \\
<5 \\
<5 \\
<5 \\
<5 \\
10 \\
<5 \\
<5 \\
<5 \\
<5 \\
<5 \\
<5 \\
<5\end{array}$ & $\begin{array}{r}<30 \\
<30 \\
40 \\
<30 \\
40 \\
<30 \\
<30 \\
<30 \\
<30 \\
<30 \\
<30 \\
<30 \\
<30\end{array}$ \\
\hline $\begin{array}{l}\text { IR-1, 108-110 } \\
\text { IR-2,4-7 } \\
\text { IR-3, 59-62 } \\
\text { IR-CC, 3-5 } \\
\text { 2R-1, 8-10 } \\
3 \mathrm{R}-1,34-37 \\
3 \mathrm{R}-2,67-70 \\
3 \mathrm{R}-3,14-16 \\
4 \mathrm{R}-1,18-20 \\
4 \mathrm{R}-2,144-146 \\
5 \mathrm{R}-1,52-53 \\
6 \mathrm{R}-1,24-26 \\
7 \mathrm{R}-1,80-82 \\
8 \mathrm{R}-1,124-126 \\
9 \mathrm{R}-1,80-82 \\
10 \mathrm{R}-1,13-15 \\
11 \mathrm{R}-1,49-51 \\
13 \mathrm{R}-1,48-49 \\
14 \mathrm{R}-1,4-6 \\
15 \mathrm{R}-1,60-62 \\
16 \mathrm{R}-1,79-81 \\
17 \mathrm{R}-1,35-36\end{array}$ & $\begin{array}{r}103 \\
8 \\
7 \\
29 \\
22 \\
32 \\
110 \\
56 \\
120 \\
32 \\
46 \\
50 \\
50 \\
16 \\
120 \\
24 \\
120 \\
42 \\
48 \\
140 \\
22 \\
100\end{array}$ & $\begin{array}{r}30 \\
620 \\
154 \\
3400 \\
<10 \\
37 \\
12 \\
25 \\
<10 \\
<10 \\
<10 \\
<10 \\
26 \\
110 \\
130 \\
100 \\
58 \\
100 \\
29 \\
58 \\
<10 \\
<10\end{array}$ & $\begin{array}{r}26.0 \\
20.0 \\
14.0 \\
60.0 \\
31.0 \\
15.0 \\
15.0 \\
10.0 \\
9.1 \\
4.0 \\
4.0 \\
5.5 \\
5.0 \\
6.5 \\
5.9 \\
6.0 \\
8.3 \\
10.0 \\
7.6 \\
5.5 \\
5.7 \\
5.0\end{array}$ & $\begin{array}{r}<0.5 \\
1.9 \\
<0.5 \\
1.1 \\
1.0 \\
1.0 \\
1.5 \\
2.2 \\
3.1 \\
2.5 \\
1.0 \\
0.8 \\
1.3 \\
2.3 \\
<0.5 \\
<0.5 \\
6.2 \\
12.0 \\
12.0 \\
5.5 \\
9.5 \\
10.0\end{array}$ & $\begin{array}{r}1.0 \\
5.0 \\
<1.0 \\
5.0 \\
6.3 \\
<1.0 \\
<1.0 \\
<1.0 \\
<1.0 \\
<1.0 \\
<1.0 \\
<1.0 \\
<1.0 \\
16.0 \\
12.0 \\
11.0 \\
14.0 \\
9.0 \\
<1.0 \\
<1.0 \\
<1.0 \\
3.0\end{array}$ & $\begin{array}{r}10.0 \\
6.1 \\
6.7 \\
8.8 \\
<1.0 \\
<1.0 \\
<1.0 \\
<1.0 \\
<1.0 \\
<1.0 \\
<1.0 \\
2.8 \\
4.3 \\
5.5 \\
7.4 \\
6.7 \\
5.5 \\
<1.0 \\
<1.0 \\
<1.0 \\
<1.0 \\
<1.0\end{array}$ & $\begin{array}{l}<5 \\
<5 \\
<5 \\
<5 \\
<5 \\
<5 \\
18 \\
11 \\
14 \\
<5 \\
<5 \\
<5 \\
<5 \\
<5 \\
<5 \\
<5 \\
<5 \\
<5 \\
<5 \\
12 \\
<5 \\
11\end{array}$ & $\begin{array}{l}<30 \\
<30 \\
<30 \\
<30 \\
<30 \\
<30 \\
<30 \\
<30 \\
<30 \\
<30 \\
<30 \\
<30 \\
<30 \\
<30 \\
<30 \\
<30 \\
<30 \\
<30 \\
<30 \\
<30 \\
<30 \\
<30\end{array}$ \\
\hline
\end{tabular}

The evident diversity in geochemical associations between the drilled deposit and previously studied sulfide deposits of sedimentfree ridge crests (Fig. 13) may be easily attributed to the change from the surface collection of samples to vertical coring. In oceanic sulfides from sediment-free ridges (Fig. 13B), sampled by conventional methods, the main gangue-mineral elements do not form separate groups, but enter, along with $\mathrm{Zn}$, a single large association corresponding to relatively low-temperature surficial parts of deposits. Thus, in the Middle Valley sulfides, elements can be divided into more groups than in the sulfides of sediment-free ridges.

Ore aggregates belonging to the two main types commonly are sampled from the surficial parts of deposits in sediment-free environments. Cu-enriched aggregates come from high-temperature chimneys and from some central parts of mature sulfide mounds (Krasnov et al., 1992). In contrast, aggregates enriched in $\mathrm{Zn}$ and gangue minerals belong to moderate-temperature chimneys and to the peripheral parts of large mounds, such as in the TAG active mound in the Atlantic (Lisitzin et al., 1990). In the Middle Valley deposit, sampled by deep coring, we found a greater variety in the types of sulfide and gangue-mineral aggregates, even in the upper part of the cored holes, which produces the observed diversity of geochemical associations.
REE patterns in the upper part of the Middle Valley deposit (Fig. 12) on the whole resemble those of the MAR sulfides from hydrothermal fields at $26^{\circ} \mathrm{N}$ and $24.5^{\circ} \mathrm{N}$ (Krasnov et al., 1992). In pyritic sulfides of zone 3 the REE pattern is more similar to those of deposits from the EPR at $13^{\circ} \mathrm{N}$.

Iron concentrations in sphalerites from Site 856 (11 to $16 \mathrm{wt} \% \mathrm{Fe}$ ) are lower than the values reported by Koski et al. (1985) for sulfide deposits of Guaymas Basin (15 to $24 \mathrm{wt} \% \mathrm{Fe}$ ). Iron concentrations in sphalerites of massive sulfides sampled from the surface on sedimentfree ridges are variable, even within individual deposits. At $44^{\circ} \mathrm{N}$ on the Juan de Fuca Ridge, the Fe concentrations are between 1 and 17 $w t \%$ in type A sulfides and $<3 \mathrm{wt} \%$ in type B sulfides (Koski et al., 1984). At $13^{\circ} \mathrm{N}$ on the EPR, Fe concentrations in zinc sulfides vary over a wide range, from low values ( 2 to $6 \mathrm{~mol} \% \mathrm{FeS}$ ) in surficial dendritic aggregates, to $35 \mathrm{~mol} \% \mathrm{FeS}$ in the Cu-enriched inner parts of chimneys (Fouquet et al., 1988). At $21^{\circ} \mathrm{N}$ on the EPR, the iron contents vary from 2 to $22 \mathrm{wt} \% \mathrm{Fe}$ at different types of vents (Oudin, 1983).

Sphalerite is depleted in most minor elements relative to sphalerites from other oceanic massive sulfide deposits (Table 11). This tendency is most evident for $\mathrm{Au}, \mathrm{Ag}, \mathrm{As}, \mathrm{Sb}$, and $\mathrm{Cr}$. It corresponds to the general depletion of the cores in minor elements in comparison with other deposits, as observed in the bulk samples (Table 5). The exceptions are $\mathrm{U}$ and $\mathrm{Ni}$ : their concentrations in sphalerite from the Middle Valley cores are higher than in those from other sites. The pyrites do not exhibit the same tendency, however, as their minor element concentrations are mostly at the same levels shown by pyrites from other regions.

Copper concentrations in $\mathrm{Cu}-\mathrm{Fe}$ sulfides (32.6 to $34.1 \mathrm{wt} \% \mathrm{Cu}$ in chalcopyrites and about $23 \mathrm{wt} \% \mathrm{Cu}$ in isocubanites) are comparable to those in the same minerals from $21^{\circ} \mathrm{N}$ on the EPR (Oudin, 1983), $13^{\circ} \mathrm{N}$ on the EPR (Fouquet et al., 1988), and $44^{\circ} \mathrm{N}$ on the Juan de Fuca Ridge (Koski et al., 1984). Oudin (1983) reported copper concentrations of 31.6 to $33.4 \mathrm{wt} \% \mathrm{Cu}$ in chalcopyrites and 21.39 to $22.95 \mathrm{wt} \%$ $\mathrm{Cu}$ in chalcopyrrhotites (isocubanites) from $21^{\circ} \mathrm{N}$ on the EPR.

\section{Model of Massive Sulfide Formation}

No significant amount of sediment was obtained in cores from the sulfide deposit at Site 856, although the core recovery at this site was relatively low ( $20 \%$ and $33 \%$ in the two deepest sulfide holes). The absence of sediment throughout the section was confirmed by logging (Shipboard Scientific Party, 1992). Thus, the sulfide body under investigation in this study, like all other sulfide deposits studied previously in the ocean (e.g., Krasnov et al., 1992), must have formed above the seafloor. In Middle Valley, the accumulation of Pleistocene sediments flanking the deposit was concurrent with its growth. However, sulfide deposition could have been interrupted during relatively short episodes. While sulfide formation was interrupted, the surface of the deposit was covered with sediments, represented now by thin, highly altered interlayers.

Evidence of pyrrhotite replacement by pyrite, described herein, shows that pyrrhotite was the main primary mineral of the cored massive sulfides. Duckworth et al. (this volume) arrived at the same conclusion, based on detailed mineralogical investigations. The formation of pyrrhotite instead of pyrite as the main sulfide mineral is typical of oceanic sites of massive sulfide deposition, where solutions pass through sedimentary cover in the course of convective circulation, as at Guaymas Basin in the Gulf of California (Koski et al., 1985), and at Escanaba Trough on the Gorda Ridge (Koski et al., 1988).

It is generally accepted that strongly reducing conditions, with low $\mathrm{fO}_{2}$ and $\mathrm{fS}_{2}$, are needed for the crystallization of pyrrhotite in oceanic hydrothermal systems (Koski et al., 1985, 1988). In black smokers at sediment-free ridges, pyrrhotite appears in certain regions (e.g., at $21^{\circ} \mathrm{N}$ on the EPR) to be the main constituent of the "smoke," as a fine-grained precipitate formed by crystallization in the solutions within their sub-bottom pathways (Haymon and Kastner, 1981). On sedimented ridges, the additional reduction of hydrothermal solutions 
through solution-sediment interaction causes the deposition of large pyrrhotite masses.

The sedimentary pile is usually a sink for the main ore metals and a source for $\mathrm{Ca}$ in these environments. In Guaymas Basin, these relationships result in a low percentage of precipitated sulfides, especially $\mathrm{Cu}$ and $\mathrm{Zn}$ sulfides, in hydrothermal deposits (Koski et al., 1985). In other oceanic sites, as in hydrothermal deposits of Gorda Ridge and the Okinawa Trough, $\mathrm{Pb}, \mathrm{As}, \mathrm{Sb}$, and $\mathrm{Sn}$ are extracted from sediments and enriched in the massive sulfides (Table 6). Some of these metals may form discrete minerals in the sulfide deposits (Koski et al., 1988; Halbach et al., 1989). The structures and textures of pyrrhotite-rich massive sulfides of zone 4 in the lower part of Hole $856 \mathrm{H}$ are similar to those previously described from Guaymas Basin (Koski et al., 1985), Gorda Ridge (Koski et al., 1988), and the surficial part of the Middle Valley deposit (Goodfellow and Blaise, 1988). Therefore, the sulfides of zone 4 are interpreted to represent primary aggregates, which, for some reason, escaped the later alteration that affected the rest of the sulfide body.

The Middle Valley deposit differs greatly in its chemical composition from deposits of some other sediment-covered spreading centers, such as Gorda Ridge and the Okinawa Trough (Table 6). At Middle Valley, the sulfide deposits contain only traces of $\mathrm{Pb}, \mathrm{As}$, and $\mathrm{Sb}$, which are believed to have been extracted from the sediments by hydrothermal solutions. Concentrations of $\mathrm{As}$ and $\mathrm{Pb}$ in sulfide deposits of Guaymas Basin are in the same range as those observed in the surficial part of the Middle Valley deposit. It is possible that the temperatures of the hydrothermal solutions that formed the deposit under study were never high enough in the shallow part of the convective system to extract significant amounts of metals from the sediments.

Prominent in the vertical element distribution of the drilled deposit is the enrichment of its upper part (zone 1) in $\mathrm{Zn}, \mathrm{Si}, \mathrm{Al}, \mathrm{Ca}, \mathrm{Mg}$, and a wide range of trace metals. Most of these elements (Ag, As, Au, $\mathrm{Ba}, \mathrm{Mn}, \mathrm{Mo}, \mathrm{Ni}, \mathrm{Sb}, \mathrm{Sn}, \mathrm{Sr}, \mathrm{Ta}, \mathrm{Tl}, \mathrm{La}, \mathrm{Sm}$, and Tb) reach their maximum values at the top of the deposit, corresponding to subzone $1 \mathrm{~A}$ of Hole $856 \mathrm{H}$. In contrast, a peak of $\mathrm{Cu}$ and $\mathrm{Se}$ enrichment is present in the lower part of zone 1 (Fig. 11).

$\mathrm{Zn}$ enrichment, characteristic of the uppermost parts of ancient massive sulfide deposits on land, is generally attributed to the zone refining process (Franklin et al., 1981; Eldridge et al., 1983). The inner structure of mature deposits is determined by the progressive upward replacement of lower temperature minerals, including $\mathrm{Zn}$ sulfides, by high-temperature $\mathrm{Cu}$ and $\mathrm{Fe}$ sulfides during growth of the sulfide bodies. In typical ancient deposits, $\mathrm{Cu}$ is enriched in the intermediate parts below zones of $\mathrm{Zn}$ enrichment; the central parts consist of the highest-temperature, coarse-grained Fe sulfides. Edmond (1980) was the first to discuss the zone refining process in connection with modern oceanic massive sulfide ore formation. Hannington et al. (1986) attributed gold enrichment in the surficial parts of large deposits on the Mid-Atlantic Ridge to the same process.

Zone refining is the most probable origin for $\mathrm{Zn}$-enriched subzone $1 \mathrm{~A}$ and $\mathrm{Cu}$-enriched subzone $1 \mathrm{~B}$ of the Middle Valley deposit. The second zone of $\mathrm{Cu}$ enrichment, in the lower part of Hole 856 H (Fig. 11), may be the result of a decline of hydrothermal activity that led to crystallization of lower-temperature chalcopyrite in interstitial spaces of the earlier-formed, highest-temperature Fe sulfides.

The vertical distribution of trace elements in pyrites (Table 11) is basically similar to that in the bulk sulfides. Thus, the zone refining process was not confined to the low-temperature minerals, which contain most of the trace elements, from lower to upper levels of the deposit. Iron sulfides were also recrystallized, with the trace metals leached from them at lower levels.

Although sphalerite shows maximum enrichment in the majority of minor elements (Table 11), it is not the only (and for some elements, even the main) host. Considering the dominance of iron sulfides in the deposit, iron sulfides should be significant hosts for most of the minor elements. However, the probable existence of small inclusions in the mineral grains limits the use of INAA data to define the actual mineral phases that contain the minor elements.

Almost all of the geochemical correlation groups, shown on Figure $13 \mathrm{~A}$, include elements $(\mathrm{Fe}, \mathrm{Cu}, \mathrm{Zn}, \mathrm{Ba}, \mathrm{Al}, \mathrm{Si}$, and $\mathrm{Ca}$ ) that evidently form the host minerals for minor elements of the same groups. Group 5, which contains the largest number of elements, including Sb and As, presumably is associated with sulfosalts. Hannington et al. (1986) discovered the important role of sulfosalt minerals in concentrating certain minor elements, including $\mathrm{Au}$, in oceanic massive sulfide deposits.

\section{Secondary Alteration of the Deposit}

The main features of the distribution of metals in Hole $856 \mathrm{H}$ are repeated in Hole $856 \mathrm{G}$, except for the enrichment of $\mathrm{Zn}$ and associated metals in the uppermost part (Fig. 11). The apparent differences between the two holes in the extent of replacement of primary pyrrhotite by pyrite did not influence the metal zoning. The vertical distribution of metals was determined by zone refining that took place during formation of the sulfide deposit, mostly in its later stages. The pervasive processes of pyrrhotite replacement occurred later, when the deposit had already formed, and did not affect the lowest part of the deposit that was reached by drilling (zone 4 in Hole $856 \mathrm{H}$ ), and only partly affected zone 2 .

In zone 3 (Holes $856 \mathrm{G}$ and $856 \mathrm{H}$ ), pyrrhotite was replaced by almost pure pyrite. Such a replacement process requires an additional source of sulfur, and reflects more oxidizing conditions compared to those of primary pyrrhotite formation. In the overlying magnetitebearing zones, oxidation was much more intense.

A positive correlation is evident between pyrite and magnetite concentrations in magnetite-bearing zones from the studied cores (Shipboard Scientific Party, 1992). These two minerals presumably formed as a result of a single process, when sulfur and oxygen were added to the system. Additional sulfur was fixed in pyrite, while oxygen and excess iron gave rise to formation of magnetite.

According to Duckworth et al. (this volume), sulfur is isotopically heavier in pyrite from Middle Valley than in pyrrhotite because of the involvement of seawater sulfate in secondary pyrite formation. The talc found in massive sulfide at different levels (from zone 3 and upward) is considered in similar geologic environments as evidence for the involvement of seawater as a source for the $\mathrm{Mg}$ (Koski et al., 1985).

Sphalerite redeposition during secondary alteration may explain the uniform iron concentration (11 to $16 \mathrm{wt} \% \mathrm{Fe}$ ) in the analyzed sphalerites (Table 7). This contrasts strongly with the widely varying Fe concentrations in $\mathrm{Zn}$ sulfides from the surficial parts of most other oceanic sulfide deposits (see above). The low Fe concentration in the sample from zone 3 may indicate higher S2 fugacities of the solutions during alteration of this zone (e.g., Scott and Kissin, 1973).

Only preliminary assumptions can be made concerning the geometry of the secondary hydrothermal convection. Below we discuss the variety of indirect evidence that favors a shallow, sill-driven, secondary convective system.

The small but distinct, positive anomaly of sediment-derived metals ( $\mathrm{Pb}, \mathrm{Sb}, \mathrm{As}, \mathrm{Ge}$, and $\mathrm{Tl})$ in the sulfides of the most strongly altered zone 3 is significant (Fig. 11). Considering the mineral chemistry and element correlations, this anomaly cannot be attributed simply to the association of these metals with pyrite, particularly as pyritic subzone $1 \mathrm{~B}$ lacks signs of their enrichment. Enrichment of zone 3 in sedimentderived metals during secondary alteration is therefore probable.

Zone 3 is also the only part of the sulfide deposit that shows a positive Eu anomaly and no dominance of LREEs over HREEs (Fig. 12). Europium is the only rare earth element subject to reduction to the $2+$ form. In this valence it preferentially fractionates into plagioclase during magmatic processes, replacing $\mathrm{Ca}$. Plagioclase phenocrysts that form in magmatic systems also preferentially concentrate 

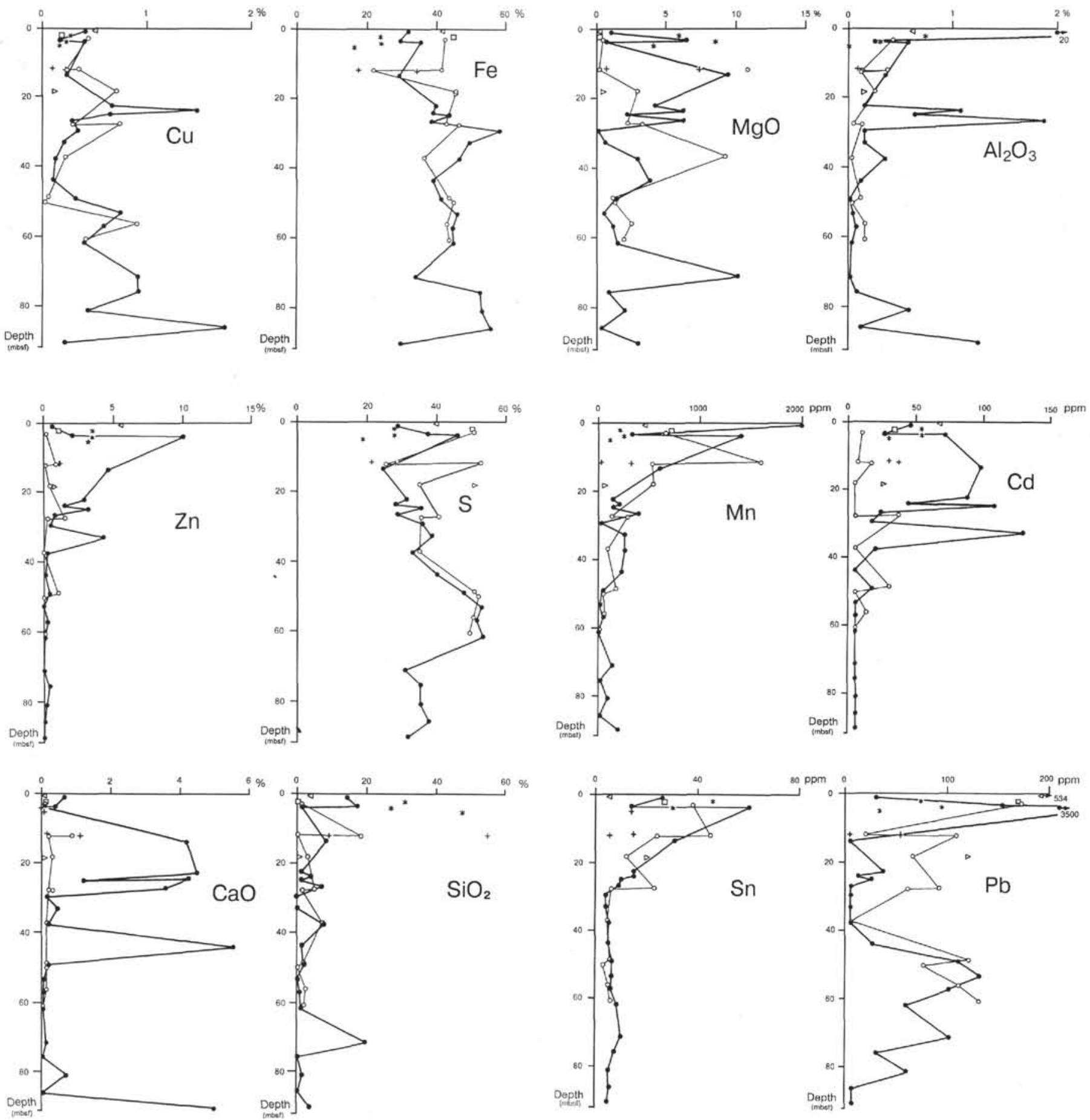

Figure 11. Element distribution vs. depth for massive sulfide samples from Site 856 . Solid circles connected by heavy lines correspond to samples from Hole $856 \mathrm{H}$, open circles connected with thin lines are from Hole $856 \mathrm{G}$, right-pointing triangles are from Hole $856 \mathrm{~B}$, left-pointing triangles from Hole $856 \mathrm{C}$, asterisks from Hole 856D, squares from Hole 856E, and crosses from Hole 856F.

heavy REEs (Graf, 1977). Thus, the supply of additional Eu and HREEs into hydrothermal solutions, concentrated in the massive sulfides, is usually explained by alteration of plagioclase.

Hole $856 \mathrm{~B}$, drilled in sediments immediately adjacent to the sulfide deposit, shows intense plagioclase alteration at a depth of more than 70 mbsf (Shipboard Scientific Party, 1992). The high Ca concentration in pore waters in this hole also supports the existence of this process. Thus, plagioclase in the sediments flanking the sulfide de- posit is the most probable source for the additional Eu and HREE enrichment noted in our massive sulfide samples.

It is difficult to determine whether the two types of sulfide alteration, namely in zone 3 and in the upper part of the deposit, resulted from a single process. At elevated temperatures, heated seawater evolved to form a hydrothermal solution due to interaction with sediments. Most probably, this solution entered the sulfide deposit at different stratigraphic levels, passing through permeable turbidite lay- 


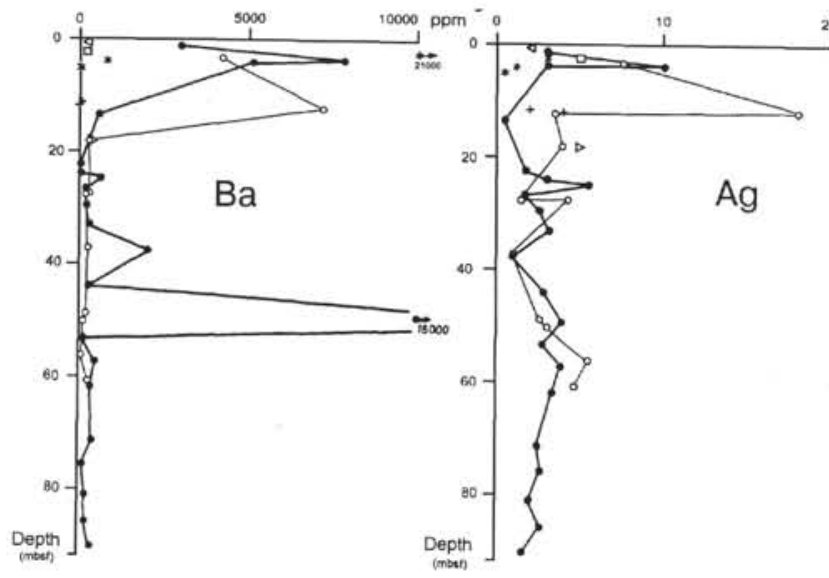
$20 \mathrm{ppm}$
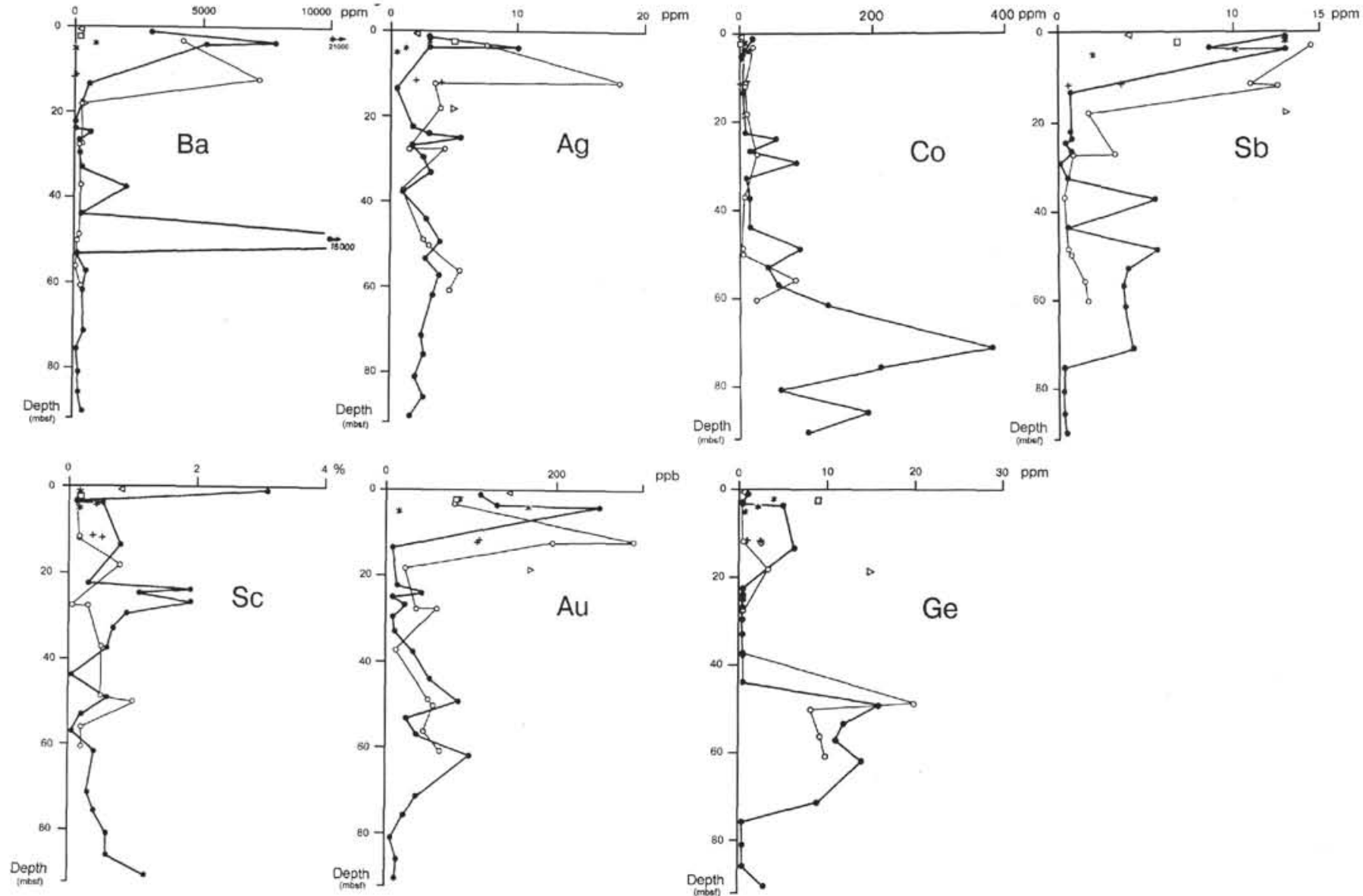
$\mathrm{ppb}$
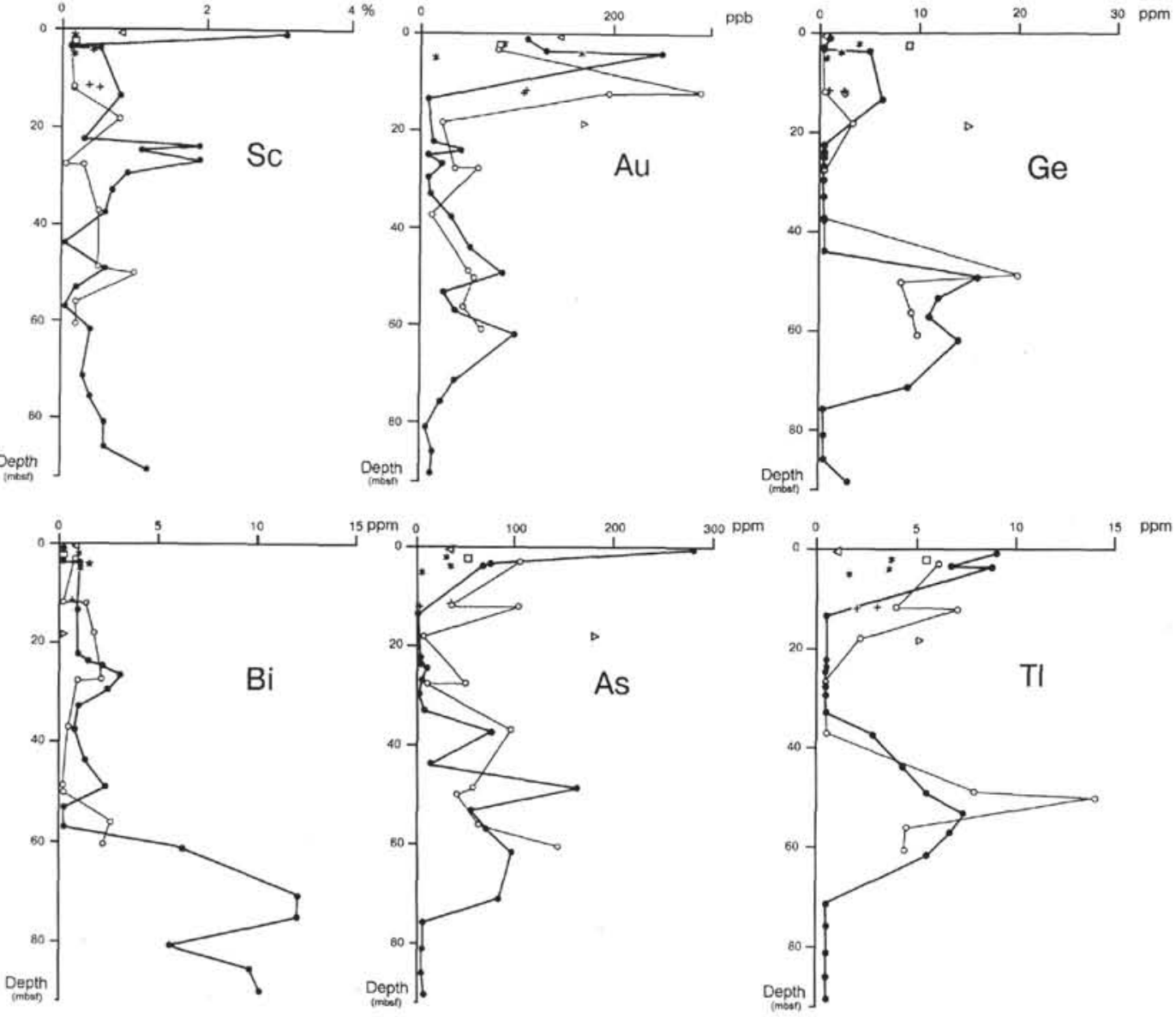

Figure 11 (continued).

ers. Such layers readily channelize solution flow in the Middle Valley hydrothermal systems (ODP Leg 139 Scientific Drilling Party, 1992). Notably, the negative sulfate anomaly at $78 \mathrm{mbsf}$ in Hole $856 \mathrm{~B}$, which corresponds to the base of zone 3 in Hole $856 \mathrm{H}$, may be evidence for lateral flow (Shipboard Scientific Party, 1992). The ascending flow of these secondary solutions passed through the pores and cracks in the sulfide deposit.

At higher levels, under mild geothermal conditions, the seawater that entered the sulfide deposit must have been less geochemically evolved. It probably retained part of its original sulfate, which caused strong oxidation of the sulfides. The more evolved solutions of the deeper, higher-temperature part of the sedimentary column are responsible for the alteration seen in zone 3 . In these latter solutions, the retained seawater sulfur was reduced to $S^{-}$from interaction with the sediments. The solutions also are likely to have retained some seawater $\mathrm{Mg}$, which was fixed in the talc of zone 3 and in the upper part of the deposit.

The scale of the alteration suggests that secondary convection may have been driven by the intrusion of one of the sills common in the sedimentary sequence at Site 856. Sill intrusions, related to the formation of Bent Hill, occurred later than the formation of the sulfide deposit (Stakes and Franklin, this volume). In Hole 856B there is no sill at a depth corresponding to the base of sulfide reworking in Hole $856 \mathrm{H}$. Yet this fact does not contradict the model, and the absence of a correlation of sills between Holes 856A and 856B (Shipboard Scientific Party, 1992) still permits a relatively small lateral continu- 

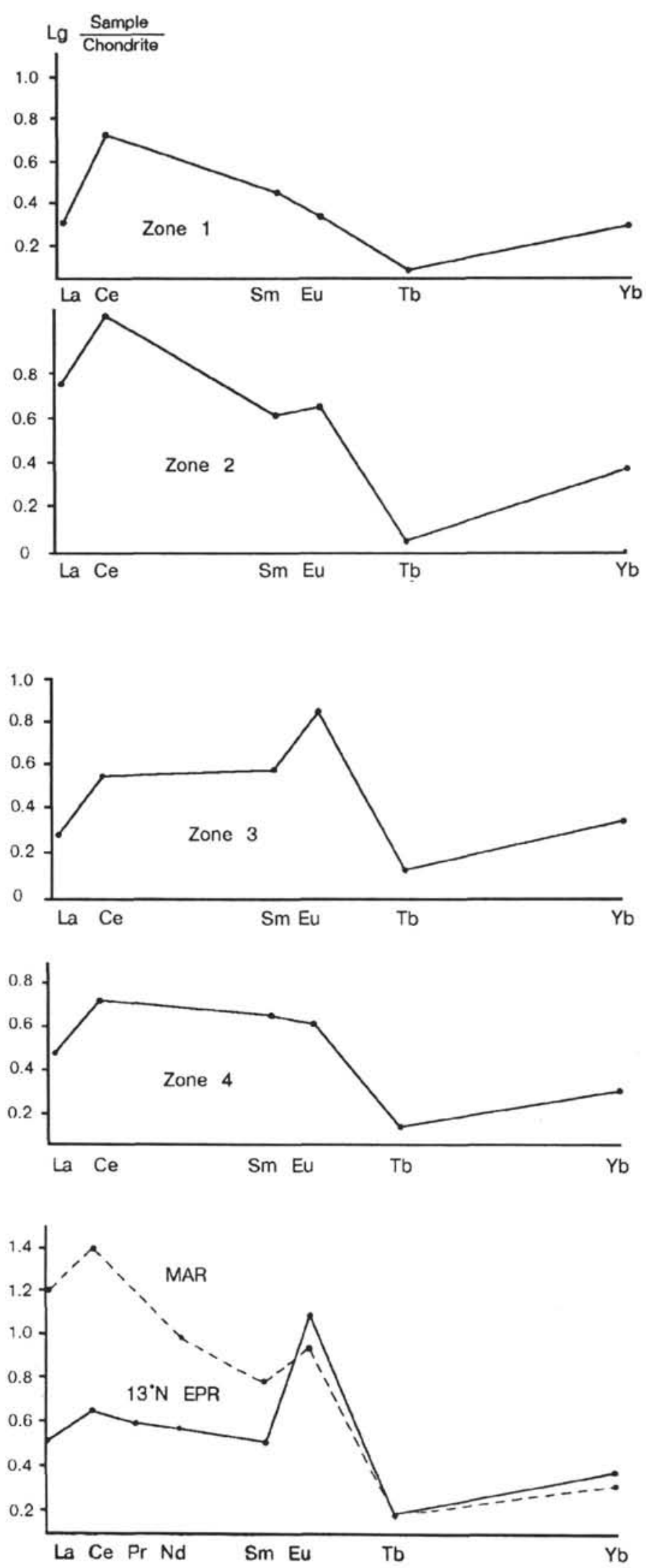

Figure 12. Average chondrite-normalized REE patterns concentrations in bulk massive sulfide samples from four different zones of Hole $856 \mathrm{H}$, and from the Mid-Atlantic Ridge (MAR) and East Pacific Rise (EPR). Chondrite values from Taylor and McLennan (1985). ity of the sills in the subsurface. A sill intrusion could heat secondary hydrothermal solutions in its vicinity to higher temperatures than any distant magmatic source. This would explain the later mobility of sediment-derived metals that remained relatively immobile during the earlier formation of the main part of the sulfide deposit.

Secondary hydrothermal systems are also associated with the sills that penetrate the sedimentary cover in Guaymas Basin, Gulf of California (Gieskes et al., 1982). These sill intrusions caused expulsion of the pore waters that formed special types of hydrothermal precipitates on the seafloor, such as talc-sulfide deposits (Lonsdale et al., 1980). The formation of larger carbonate-sulfate-sulfide chimneys associated with sill-derived mounds near the axis of Guaymas Basin has also been attributed by some authors to secondary silldriven hydrothermal systems (Lisitzin et al., 1990). Although the relative proportions of pore water and seawater participation in secondary hydrothermal activity may be different, on the whole we believe that the Guaymas Basin model is applicable to Middle Valley.

A schematic reconstruction of the cored massive sulfide deposit is shown in Figure 14. It presents the formation of the deposit by an upflow of hydrothermal solutions, genetically related to a relatively deep-seated magmatic body, and its subsequent partial alteration by lateral flow of secondary solutions, related to a sill. In reality the process was undoubtedly not that simple, and the differences between the cores from Holes $856 \mathrm{G}$ and $856 \mathrm{H}$ suggest a complex threedimensional geometry of secondary alteration of the deposit.

\section{SUMMARY AND CONCLUSIONS}

Primary pyrrhotite in a large, inactive massive sulfide deposit, drilled at Site 856 in Middle Valley, formed above the sedimentary cover, probably from hydrothermal solutions with low $\mathrm{fO}_{2}$ and $\mathrm{fS}_{2}$, which are typical of sedimented ridges. The sediments, however, did not contribute significant quantities of $\mathrm{Pb}, \mathrm{Sb}$, and $\mathrm{As}$ to the hydrothermal solutions or to sulfide minerals, as at hydrothermal systems on Gorda Ridge and the Okinawa Trough. One possible reason for this lack of sedimentary contribution is that the temperature of the solutions in the upper part of the Middle Valley hydrothermal system was too low to extract metals from the sediments.

In terms of ore petrology, the drilled deposit has a complex inner structure. The correlation of sulfide facies between the two drilled deep holes, $856 \mathrm{G}$ and $856 \mathrm{H}$, is not always possible. Essentially, $\mathrm{Zn}$ and almost all of the trace metals are scarce in the inner part of the sulfide deposit. $\mathrm{Zn}$ and trace metal concentrations increase in the outer part of the deposit (to about $28 \mathrm{mbsf}$ in Hole $856 \mathrm{H}$ ), as a result of zone refining.

The zone refining process of progressively upward replacement of comparatively low-temperature mineral phases by higher temperature minerals took place during later stages of the growth of the deposit. This process led to the mobilization of trace elements contained within the low-temperature phases. Apart from maximum $\mathrm{Zn}$ and trace metal enrichment in the surficial part of the deposit, the zone refining caused $\mathrm{Cu}$ enrichment in the subsurface ( 18 to $28 \mathrm{mbsf}$ in Hole $856 \mathrm{H}$ ). Similar vertical variations in $\mathrm{Zn}$ and $\mathrm{Cu}$ concentrations are typical of ancient massive sulfide deposits on land. Copper enrichment in the deepest drilled part of the deposit most likely formed during the waning stage of high-temperature hydrothermal activity.

Two types of alteration of primary pyrrhotite were connected with an intense post-depositional hydrothermal reworking process: (1) almost complete pyritization of pyrrhotite in the lower central part of the cored section ( 48 to $75 \mathrm{mbsf}$ in Hole $856 \mathrm{H}$ ) and (2) replacement of pyrrhotite by pyrite-magnetite aggregates in the upper part. Primary pyrrhotite is only preserved in the lowest drilled part of the deposit.

The presence of talc in secondary reworked sulfides shows that seawater, evolved to different extent, participated in both types of alteration. Seawater sulfate took part in the strongly oxidizing alteration in the upper part of the deposit. Below, under higher temperature 
conditions, more geochemically evolved seawater probably contained sulfur mainly in reduced form that caused pyritization.

The secondary convection systems could have been driven by heat from one of the sills that intruded the upper part of the sedimentary column following the main stage of sulfide formation. Evolved seawater entered the deposit laterally at different levels, possibly through permeable turbidite layers. A small but definite enrichment of secondary pyritic sulfide in sediment-derived elements such as $\mathrm{Pb}, \mathrm{Sb}$, and $\mathrm{As}$, formed by lateral flow in the vicinity of the sill. The temperature here was sufficiently high for extracting metals from the sediments on the flanks of the sulfide deposit. The absence of LREE enrichment and the existence of a positive Eu anomaly in the pyritic sulfide may be due to release of additional Eu and HREE into secondary solutions from hydrothermally decomposed plagioclase in the turbidites.

\section{ACKNOWLEDGMENTS}

The German Agency for Academic Exchange (DAAD) funded the research stay of the first two authors at Marburg University, during which polished sections were prepared, described, and photographed, along with statistical processing of geochemical data. We are most grateful to Prof. Werner Tufar and the staff of his laboratory in Marburg for organizing this visit and for their constant support of our work. We also would like to thank Dr. Andreas Schaper for taking the SEM photos, and Drs. Ye. Yel'yanova and Ye. Baranov for helpful discussions. We appreciate the participation of $\mathrm{O}$. Khaleneva, who drafted the figures.

\section{REFERENCES}

Baedecker, P.A., and McKown, D.M., 1987. Instrumental neutron-activation analysis of geochemical samples. U.S. Geol. Surv. Bull., 1770:H1-H14.

Chernyakhovskaya, V.Z., and Osyko, Y.P., 1983. Catalogue of Standard Rock Samples: Moscow (VIMS). (in Russian)

Davis, E.E., Goodfellow, W.D., Bornhold, B.D., Adshead, J., Blaise, B., Villinger, H., and Le Cheminant, G.M., 1987. Massive sulfides in a sedimented rift valley, northern Juan de Fuca Ridge. Earth Planet. Sci. Lett., 82:49-61.

Edmond, J.M., 1980. Ridge crest hot springs: the story so far. Eos, 61:129-132.

Eldridge, C.S., Barton, P.B., Jr., and Ohmoto, H., 1983. Mineral textures and their bearing on formation of the Kuroko ore bodies. In Ohmoto, $\mathrm{H}$., and Skinner, B.J. (Eds.), The Kuroko and Related Volcanogenic Massive Sulfide Deposits. Econ. Geol. Monogr., 5:241-281.

Fouquet, Y., Auclair, G., Cambon, P., and Etoubleau, J., 1988. Geological setting and mineralogical and geochemical investigations on sulfide deposits near $13^{\circ} \mathrm{N}$ on the East Pacific Rise. Mar. Geol., 84:143-178.

Franklin, J.M., Lydon, J.W., and Sangster, D.F., 1981. Volcanic-associated massive sulfide deposits. Econ. Geol., 75th Anniver. Vol., 485-627.

Gieskes, J.M., Kastner, M., Einsele, G., Kelts, K., and Niemitz, J., 1982. Hydrothermal activity in the Guaymas Basin, Gulf of California: a synthesis. In Curray, J.R., Moore, D.G., et al., Init. Repts. DSDP, 64: Washington (U.S. Govt. Printing Office), 1159-1167.

Goodfellow, W.D., and Blaise, B., 1988. Sulphide formation and hydrothermal alteration of hemipelagic sediment in Middle Valley, northern Juan de Fuca Ridge. Can. Mineral., 26:675-696.

Graf, J.L., 1977. Rare earth elements as hydrothermal tracers during the formation of massive sulfide deposits in volcanic rocks. Econ. Geol. 72:527-548.

Halbach, P., Nakamura, K., Washner, M., Lange, J., Sakai, H., Kaselitz, L. Hansen, R.D., Yamano, M., Post, J., Prause, B., Seifert, R., Michaelis, W. Teichmann, F., Kinoshita, M., Marten, A., Ishibashi, J., Czerwinski, S., and
Blum, N., 1989. Probable modern analogue of Kuroko-type massive sulfide deposits in the Okinawa Trough back-arc basin. Nature, 338:496499.

Hannington, M.D., Peter, J.M., and Scott, S.D., 1986. Gold in sea-floor polymetallic sulfide deposits. Econ. Geol., 81:1867-1883.

Haymon, R.M., and Kastner, M., 1981. Hot spring deposits on the East Pacific Rise at $21^{\circ} \mathrm{N}$ : preliminary description of mineralogy and genesis. Earth Planet. Sci. Lett., 53:363-381.

Honnorez, J., Mevel, C., and Honnorez-Guerstein, B.M., 1990. Mineralogy and chemistry of sulfide deposits drilled from hydrothermal mound of the Snake Pit active field, MAR. In Detrick, R., Honnorez, J., Bryan, W.B., Juteau, T., et al. Proc. ODP, Sci. Results, 106/109: College Station, TX (Ocean Drilling Program), 145-162.

Kappel, E.S., and Franklin, J.M., 1989. Relationships between geologic development of ridge crests and sulfide deposits in the northeast Pacific Ocean. Econ. Geol., 84:485-505.

Koski, R.A., Clague, D.A., and Oudin, E., 1984. Mineralogy and chemistry of massive sulfide deposits from the Juan de Fuca Ridge. Geol. Soc. Am. Bull., 95:930-945.

Koski, R.A., Lonsdale, P.F., Shanks, W.C., Berndt, M.E., and Howe, S.S., 1985. Mineralogy and geochemistry of a sediment hosted hydrothermal sulfide deposit from the southern trough of Guaymas basin, Gulf of California. J. Geophys. Res., 90:6695-6707.

Koski, R.A., Shanks, W.C., III, Bohrson, W.A., and Oscarson, R.L., 1988. The composition of massive sulfide deposits from the sediment-covered floor of Escanaba Trough, Gorda Ridge: implications for depositional processes. Can. Mineral., 26:655-673.

Krasnov, S.G., Cherkashev, G.A., Ainemer, A.I., Grintal, E.F., Grichuk, D.V., Davydov, M.P., Poroshina, I.M., Stepanova, T.V., Sudarikov, S.M., Bochek, L.I., Datzenko, V.A., Dubinin, Y.P., Yel'yanova, Ye.A., Zairi, N.M., Kolosov, O.V., Mironov, Yu.V., Popov, V.Y., Andreeva, I.A., Vaganov, P.A., German, N.Y., Gurevich, N.I., Kreyter, I.I., and Maslov, M.N., 1992. Hydrothermal Sulfide Ores and Metalliferous Sediments of the Ocean: St. Petersburg (Nedra). (in Russian)

Lisitzin, A.P., Bogdanov, Y.A., and Gurvich, Y.G., 1990. Hydrothermal Deposits of Oceanic Rift Zones: Moscow (Nauka). (in Russian)

Lonsdale, P.F., Bishoff, J.L., Burns, V.M., Kastner, M., and Sweeney, R.E., 1980. A high-temperature hydrothermal deposit on the seabed at a Gulf of California spreading center. Earth Planet. Sci. Lett., 49:8-20.

ODP Leg 139 Scientific Drilling Party, 1992. Hot rocks and massive sulfide: northern Juan de Fuca Ridge. Eos, 73:193-198.

Oudin, E., 1983. Hydrothermal sulfide deposits of the East Pacific Rise $\left(21^{\circ} \mathrm{N}\right)$. Part 1: descriptive mineralogy. Mar. Min., 4:39-72.

Scott, S.D., and Kissin, J., 1973. Sphalerite composition in the Zn-Fe-S system below $300^{\circ}$. Econ. Geol., 68:475-479.

Shipboard Scientific Party, 1992. Site 856. In Davis, E.E., Mottl, M.J., Fisher, A.T., et al., Proc. ODP, Init. Repts., 139: College Station, TX (Ocean Drilling Program), 161-281.

Taylor, S.R., and McLennan, S.M., 1985. The Continental Crust: Its Composition and Evolution: Oxford (Blackwell Scientific).

Vaganov, P.A., 1975. On the possibility of using a monostandard in neutronactivation analysis of rock samples. Sci. Notes Leningr. State Univ., Ser. Phys. Geol. Sci., 25:125-127. (in Russian)

\footnotetext{
- Abbreviations for names of organizations and publications in ODP reference lists follow the style given in Chemical Abstracts Service Source Index (published by American Chemical Society).
}

Date of initial receipt: 1 December 1992

Date of acceptance: 30 August 1993

Ms 139SR-230 
Table 6. Comparison between bulk chemical composition of oceanic massive sulfides from Middle Valley and other locations.

\begin{tabular}{|c|c|c|c|c|c|c|c|c|c|c|c|c|c|c|c|}
\hline Location & $\mathrm{Fe}$ & $\mathrm{Cu}$ & $\mathrm{Zn}$ & $\mathrm{S}$ & $\mathrm{Mg}$ & Al & $\mathrm{Si}$ & $\mathrm{Ca}$ & $\mathrm{Ba}$ & Mn & $\mathrm{Pb}$ & $\mathrm{Cr}$ & Co & $\mathrm{Ni}$ & As \\
\hline \multicolumn{16}{|l|}{ Mid-Atlantic Ridge } \\
\hline $26^{\circ} \mathrm{N}$ & 30.25 & 1.62 & 1.29 & 34.27 & 0.068 & 0.19 & 1.55 & 0.25 & 0.087 & 0.035 & 446 & 14.8 & 103.8 & 38.0 & 67.5 \\
\hline $24^{\circ} 30^{\prime} \mathrm{N}$ & 17.55 & 16.25 & 4.06 & & & & & & 0.053 & 0.026 & 262 & 27.9 & 15.9 & 45.0 & 61.5 \\
\hline \multicolumn{16}{|l|}{ East Pacific Rise } \\
\hline $13^{\circ} \mathrm{N}$ & 26.13 & 1.91 & 2.36 & & 0.160 & 0.33 & 1.03 & 0.34 & 0.050 & 0.092 & 150 & & 88.6 & & 51.3 \\
\hline $21^{\circ} \mathrm{N}$ & 23.12 & 0.61 & 5.93 & 38.71 & 0.022 & 0.16 & 1.29 & & 0.069 & 0.029 & 1161 & 15.7 & 44.1 & 2.7 & 430.5 \\
\hline $9^{\circ} 40^{\prime} \mathrm{N}$ & 33.02 & 3.59 & 1.99 & 38.00 & & 0.19 & 0.96 & 0.16 & & 0.010 & 102 & & 22.3 & & \\
\hline $22^{\circ} \mathrm{S}$ & 28.68 & 1.30 & 2.80 & 227 & & & & & & & & & & & \\
\hline \multicolumn{16}{|l|}{ Juan de Fuca } \\
\hline Axial Seamount & 5.03 & 0.61 & 28.84 & & 20.72 & 0.17 & 10.25 & 0.17 & & 0.039 & 2148 & 12.3 & 10.5 & 25.8 & 711.2 \\
\hline Cleft Segment & 24.74 & 0.056 & 11.48 & 42.55 & & 0.08 & 4.17 & & 0.029 & 0.120 & 1820 & 12.0 & 5.4 & & 420.7 \\
\hline Explorer Ridge & 21.91 & 4.83 & 1.65 & 29.07 & & & 2.99 & & 1.640 & & 275 & & & & 241.0 \\
\hline Galapagos Ridge & 30.37 & 4.94 & 1.17 & 52.20 & & 0.45 & 6.91 & 0.11 & & 0.023 & 226 & 54.9 & 94.8 & 25.4 & 123.9 \\
\hline Guaymas Basin & 35.61 & 0.55 & 1.19 & 26.37 & 0.36 & 0.07 & 3.81 & 2.66 & 0.170 & 0.155 & 711 & & 67.0 & 29.7 & 476.4 \\
\hline Gorda Ridge & 36.79 & 1.09 & 1.57 & 32.75 & & & & & 0.200 & 0.005 & 9120 & & & & 4436.1 \\
\hline Okinawa Trough ${ }^{a}$ & 8.59 & 1.40 & 23.36 & & 0.04 & 0.05 & 4.80 & 0.06 & 3.360 & 0.180 & $15.94 \%$ & & & & $3.08 \%$ \\
\hline \multicolumn{16}{|l|}{ Middle Valley } \\
\hline Surface samples & 30.30 & 0.40 & 2.47 & 26.00 & 2.92 & 1.56 & 8.13 & 0.32 & 1.97 & 0.092 & 400 & & 25.0 & 95.0 & 227.0 \\
\hline Cores (this study) & & & & & & & & & & & & & & & \\
\hline Average & 39.51 & 0.43 & 1.41 & 38.07 & 1.92 & 0.43 & 3.80 & 0.66 & 0.19 & 0.033 & 152 & 26.0 & 43.4 & 32.4 & 51.3 \\
\hline Median & 42.08 & 0.32 & 0.53 & 35.75 & 1.26 & 0.08 & 1.24 & 0.14 & 0.03 & 0.019 & 56 & 20.0 & 11.1 & 27.5 & 34.5 \\
\hline Std. dev. & 9.67 & 0.36 & 2.02 & 9.85 & 1.88 & 1.68 & 5.87 & 1.12 & 0.43 & 0.043 & 534 & 19.1 & 73.9 & 22.8 & 59.4 \\
\hline
\end{tabular}

Table 7. Correlation coefficients for the elements of the Middle Valley massive sulfides calculated using the data on the 40 bulk samples analyzed (Table 5).

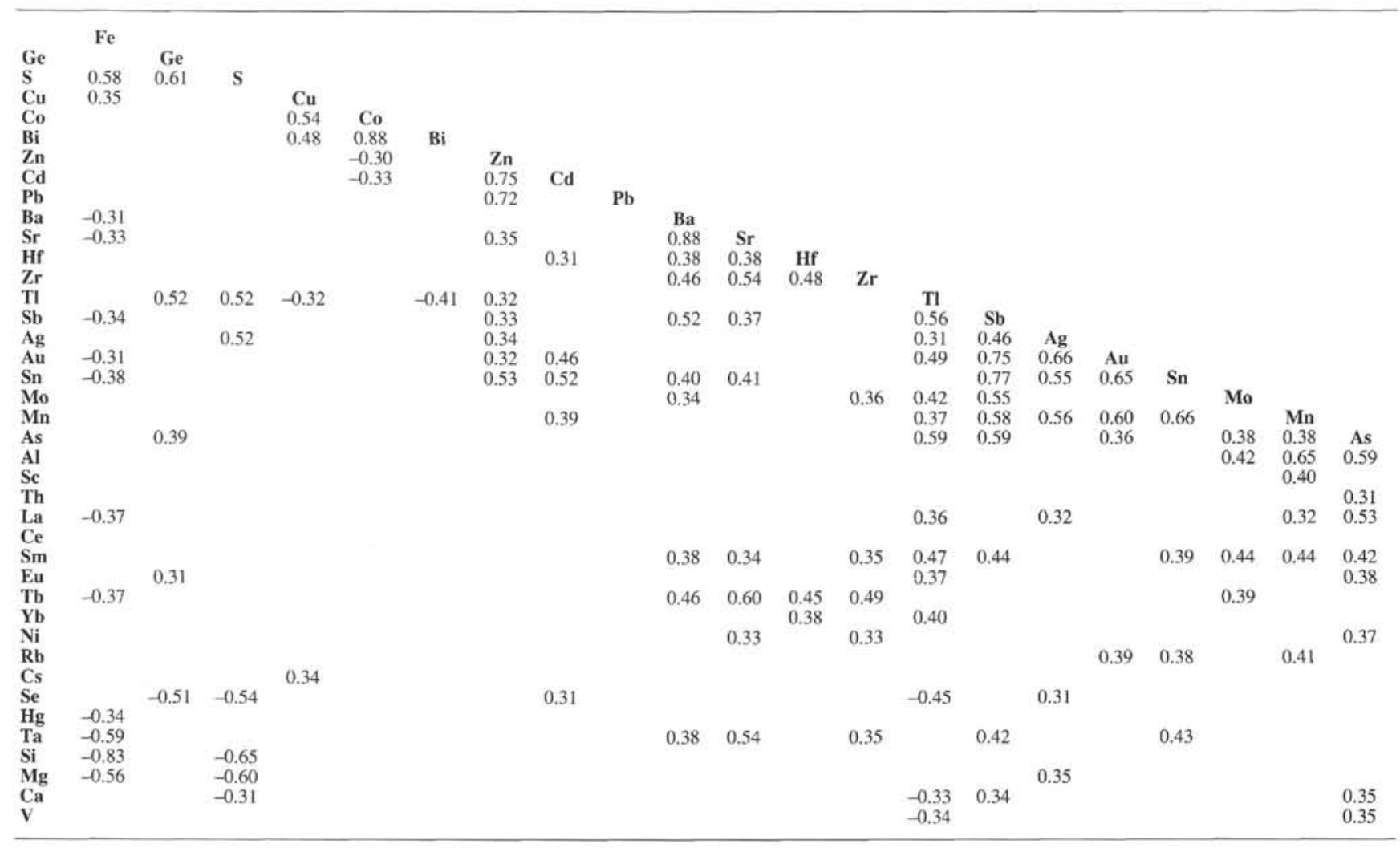

Note: Only coefficients significant at the $95 \%$ confidence level are shown. 
Table 6 (continued).

\begin{tabular}{|c|c|c|c|c|c|c|c|c|c|c|c|c|c|c|c|c|}
\hline Location & $\mathrm{Se}$ & $\mathrm{Sr}$ & Mo & $\mathrm{Cd}$ & $\mathrm{Sb}$ & $\mathrm{Hg}$ & $\mathrm{Ti}$ & Sn & $\mathrm{Bi}$ & $\mathrm{Ge}$ & $\mathrm{Tl}$ & $\mathrm{Ag}$ & $\mathrm{Au}$ & $\mathrm{U}$ & Sc & $\mathrm{Rb}$ \\
\hline \multicolumn{17}{|l|}{ Mid-Atlantic Ridges } \\
\hline $26^{\circ} \mathrm{N}$ & & 323.6 & 115.1 & 52.0 & 11.6 & & 0.027 & 10.0 & & & & 48.6 & 1.03 & & 1.3 & 52.6 \\
\hline $24^{\circ} 30^{\prime} \mathrm{N}$ & & & & & 8.9 & 0.05 & 0.012 & & & & & 42.7 & 10.40 & & 1.3 & 45.8 \\
\hline \multicolumn{17}{|l|}{ East Pacific Rise } \\
\hline $13^{\circ} \mathrm{N}$ & 7.8 & & 20.1 & 48.7 & & & 0.010 & 10.0 & & 10.0 & & 38.6 & 0.26 & & 1.9 & 35.1 \\
\hline $21^{\circ} \mathrm{N}$ & 22.9 & 33.5 & 24.8 & 493.2 & 31.4 & & & & & & & 172.6 & 0.18 & & 0.3 & 3.26 \\
\hline $9^{\circ} 40^{\prime} \mathrm{N}$ & & & 110.7 & 28.2 & & & 0.002 & 10.0 & & & 9.7 & 9.2 & 0.06 & & & \\
\hline $22^{\circ} \mathrm{S}$ & & & & & & & & & & & & 36.6 & 0.15 & & 0.9 & 24.8 \\
\hline Juan de Fuca & & & & & & 0.5 & & & 0.15 & & & & & & & \\
\hline Axial Seamount & 2.3 & 668.3 & 35.7 & 549.5 & 267.3 & & & & & & & 165.2 & 4.42 & & 1.5 & 60.0 \\
\hline Cleft Segment & 28.9 & 30.0 & 10.4 & 134.0 & 4.9 & & & & & & & 63.1 & 0.13 & & & \\
\hline Explorer Ridge & 53.7 & 108.4 & 119.4 & 70.1 & 15.0 & & & & 3.3 & & 36.8 & 0.55 & & & & \\
\hline Galapagos Ridge & 100.0 & & 169.8 & 32.0 & 7.2 & & & & & & & 37.5 & 0.20 & & & 23.5 \\
\hline Guaymas Basin & & & & 114.8 & & & & & & & & 15.1 & 0.07 & & 1.8 & 70.0 \\
\hline Gorda Ridge & & & & 54.8 & 255.3 & & & 12.5 & & 10.0 & 2.5 & 85.9 & 1.40 & & & \\
\hline Okinawa Trough ${ }^{a}$ & & 1200.0 & & 600.0 & & & & & & & & 2500.0 & 5.50 & & & \\
\hline \multicolumn{17}{|l|}{ Middle Valley } \\
\hline Surface samples ${ }^{\mathrm{b}}$ & 87.7 & & 108.0 & 39.5 & 26.9 & & 0.006 & & 0.64 & & & 8.70 & 0.14 & & & \\
\hline \multicolumn{17}{|l|}{ Cores (this study): } \\
\hline Average & 41.81 & 213.6 & 23.7 & 30.1 & 4.2 & 18.2 & 0.006 & 14.9 & 2.35 & 4.3 & 3.39 & 3.54 & 0.007 & 5.97 & 0.59 & 22.03 \\
\hline Median & 34.00 & 200.0 & 17.0 & 18.5 & 1.9 & 6.0 & 0.004 & 8.7 & 1.10 & & 2.90 & 3.00 & 0.004 & 4.00 & 0.43 & 22.00 \\
\hline Std. dev. & 34.15 & 129.5 & 18.1 & 31.7 & 4.7 & 43.8 & 0.006 & 13.6 & 3.17 & 5.4 & 2.95 & 2.98 & 0.007 & 5.72 & 0.60 & 12.76 \\
\hline
\end{tabular}

Table 7 (continued).

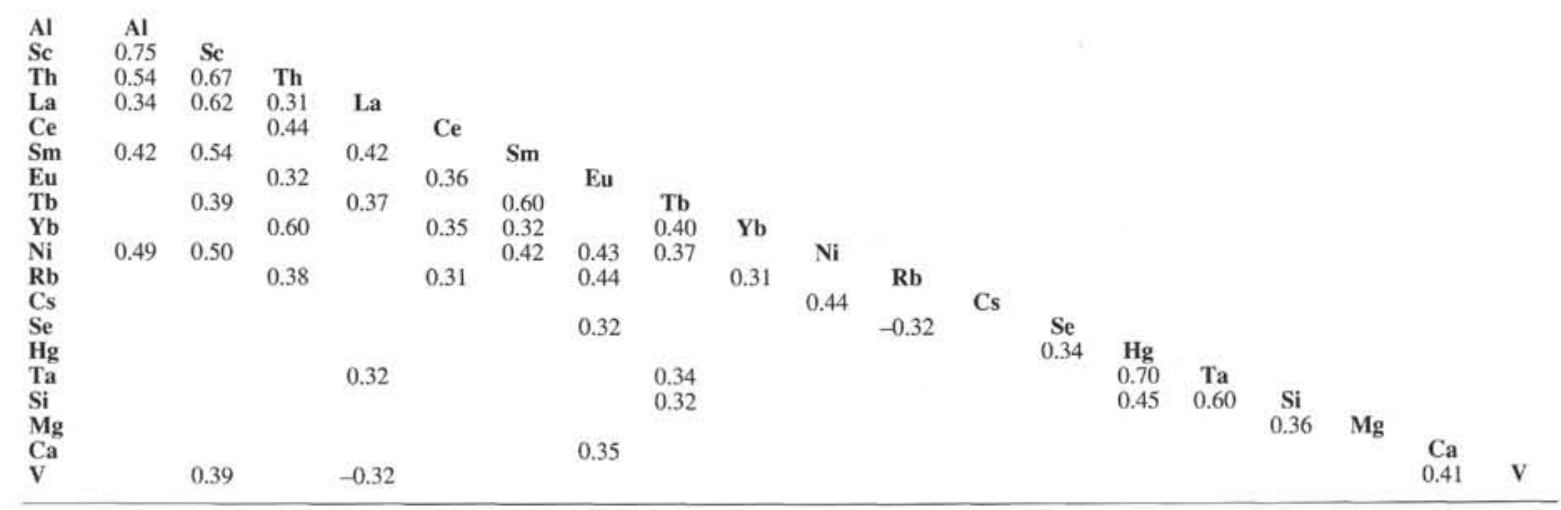


Table 6 (continued).

\begin{tabular}{|c|c|c|c|c|c|c|c|c|c|c|}
\hline Location & Cs & $\mathrm{Hf}$ & $\mathrm{Ta}$ & $\mathrm{Th}$ & $\mathrm{La}$ & $\mathrm{Ce}$ & Sm & Eu & $\mathrm{Tb}$ & $\mathrm{Yb}$ \\
\hline \multicolumn{11}{|l|}{ Mid-Atlantic Ridges } \\
\hline $26^{\circ} \mathrm{N}$ & 0.97 & 1.58 & 0.17 & 0.56 & 1.34 & 10.6 & 0.71 & 0.75 & 0.24 & 0.32 \\
\hline $24^{\circ} 30^{\prime} \mathrm{N}$ & 1.25 & 2.63 & 0.11 & 0.65 & 6.92 & 24.4 & 0.87 & 0.76 & 0.14 & 0.47 \\
\hline \multicolumn{11}{|l|}{ East Pacific Rise } \\
\hline $\begin{array}{l}13^{\circ} \mathrm{N} \\
21^{\circ} \mathrm{N}\end{array}$ & 0.26 & 1.27 & 0.31 & 0.84 & 0.97 & 3.0 & 0.38 & 0.91 & 0.19 & 0.73 \\
\hline $9^{\circ} 40^{\prime} \mathrm{N}$ & & & & & 0.85 & 0.5 & 0.26 & 0.01 & 0.05 & 0.50 \\
\hline $22^{\circ} \mathrm{S}$ & 0.32 & 1.12 & 0.09 & 0.56 & 1.82 & 13.0 & 0.58 & 0.51 & 0.22 & 0.60 \\
\hline \multicolumn{11}{|l|}{ Juan de Fuca } \\
\hline $\begin{array}{l}\text { Axial Seamount } \\
\text { Cleft Segment }\end{array}$ & 1.50 & 4.70 & 1.10 & 1.00 & 4.10 & 10.2 & 2.00 & 1.23 & 0.49 & 0.47 \\
\hline \multicolumn{11}{|l|}{ Explorer Ridge } \\
\hline Galapagos Ridge & 1.50 & 0.50 & & & 4.10 & 1.8 & & & & \\
\hline Guaymas Basin & 2.10 & 5.10 & 0.49 & 0.85 & 1.70 & 8.9 & 1.80 & 1.30 & 0.39 & 0.74 \\
\hline \multirow{2}{*}{\multicolumn{11}{|c|}{$\begin{array}{l}\text { Gorda Ridge } \\
\text { Okinawa Trougha }\end{array}$}} \\
\hline & & & & & & & & & & \\
\hline \multicolumn{11}{|l|}{ Middle Valley } \\
\hline \multirow{2}{*}{\multicolumn{11}{|c|}{ Cores (this study): }} \\
\hline & & & & & & & & & & \\
\hline Average & 0.44 & 1.11 & 0.38 & 0.36 & 1.67 & 7.2 & 1.19 & 0.46 & 0.23 & 0.78 \\
\hline Median & 0.32 & 0.91 & 0.08 & 0.30 & 1.30 & 5.0 & 1.10 & 0.40 & 0.20 & 0.70 \\
\hline Std. dev. & 0.29 & 0.68 & 0.69 & 0.29 & 1.45 & 8.2 & 0.81 & 0.25 & 0.19 & 0.68 \\
\hline
\end{tabular}

Notes: $\mathrm{Fe}, \mathrm{Cu}, \mathrm{Zn}, \mathrm{S}, \mathrm{Mg}, \mathrm{Al}, \mathrm{Si}, \mathrm{Ca}$, and $\mathrm{Ba}$ in percent (\%); all other elements in parts per million (ppm). Analytical results, except for those indicated by footnotes ${ }^{\mathrm{a}}$ or $^{\mathrm{b}}$, are represented by average values for $\mathrm{Fe}$ and $\mathrm{S}$ and median values for all other elements, from the review of Krasnov et al. (1992).

a Averages from five samples (Halbach et al., 1989).

${ }^{b}$ Averages from 10 samples for Au (Davis et al., 1987).
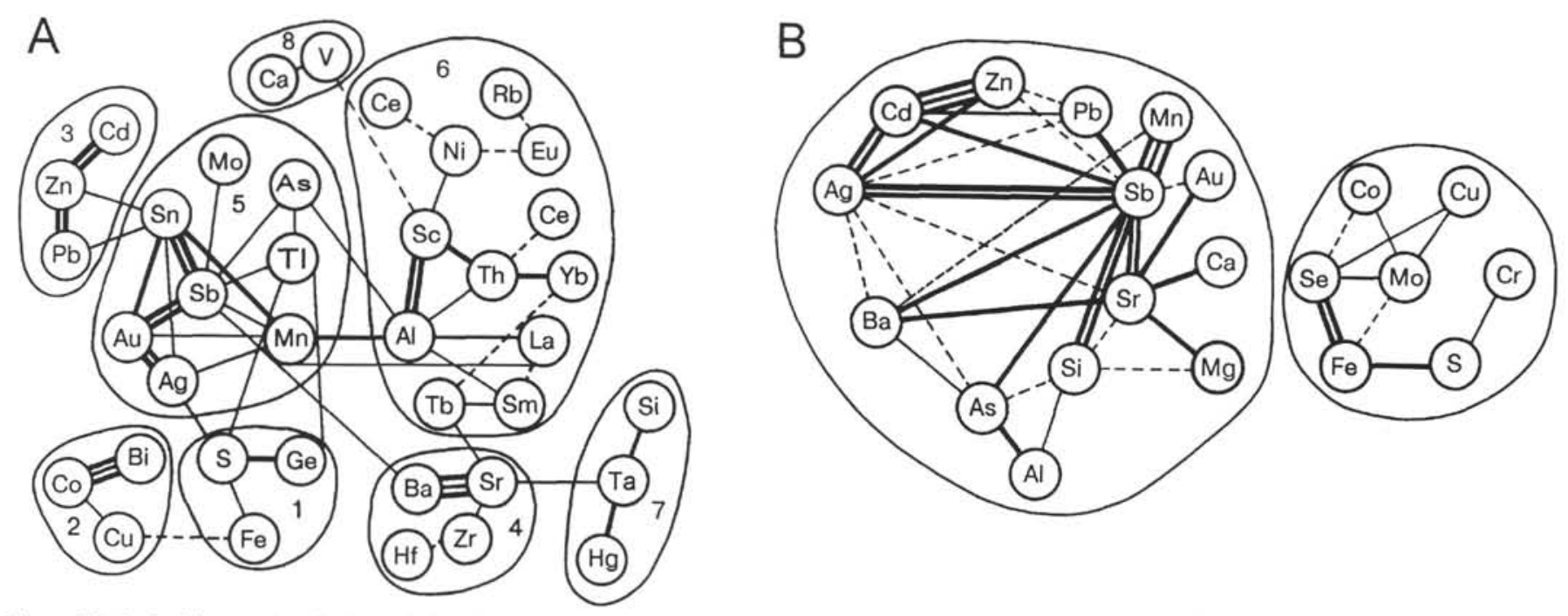

Figure 13. A. Positive geochemical correlations in bulk sulfide samples from Site 856. Correlation coefficients greater than 0.8 are shown by triple lines, those greater than 0.7 by double lines, those greater than 0.6 by thick lines, and those greater than 0.5 by thin lines. Coefficients lower than 0.4 , significant at the $95 \%$ confidence level, are shown selectively by dashed lines. Groups of associated elements are numbered from 1 to 8 (see text). B. Geochemical correlation of massive sulfide samples from sediment-free ridges (Krasnov et al., 1992). Conventions are the same as for (A). 
Table 8. Representative microprobe analyses (wt \%) of sphalerite.

\begin{tabular}{lrrrrrrl}
\hline $\begin{array}{c}\text { Core, section, } \\
\text { interval }(\mathrm{cm})\end{array}$ & $\mathrm{Fe}$ & $\mathrm{Zn}$ & $\mathrm{S}$ & $\mathrm{Cd}$ & $\mathrm{Cu}$ & Total & $\begin{array}{c}\text { Additional } \\
\text { comments }\end{array}$ \\
\hline 139-856E-1H-1, 106-108 & 15.6 & 47.7 & 35.0 & 0.19 & 0.11 & 98.60 & \\
139-856F- & & & & & & & \\
2X-CC, 1-3 & 14.4 & 49.8 & 33.8 & 0.20 & 0.00 & 98.20 & Inclusion in pyrite \\
2X-CC, 1-3 & 14.7 & 48.1 & 35.8 & 0.20 & 0.00 & 98.80 & Grain with chalcopyrite inclusion \\
139-856G- & & & & & & & \\
4R-1, 49-51 & 12.8 & 50.1 & 35.5 & 0.16 & 0.00 & 98.56 & \\
6R-2, 101-103 & 4.8 & 62.5 & 33.1 & 0.13 & 0.00 & 100.53 & \\
139-856H- & & & & & & & \\
3R-2,67-70 & 13.8 & 50.8 & 34.4 & 0.16 & 0.01 & 99.17 & Inclusion in pyrite \\
6R-1, 24-26 & 15.2 & 50.7 & 34.1 & 0.17 & 0.00 & 100.17 & \\
15R-1,60-62 & 11.3 & 52.2 & 34.7 & 0.19 & 0.50 & 98.89 & Grain with chalcopyrite inclusion \\
\hline
\end{tabular}

Table 9. Representative microprobe analyses (wt \%) of pyrite.

\begin{tabular}{|c|c|c|c|c|c|c|}
\hline $\begin{array}{l}\text { Core, section, } \\
\text { interval }(\mathrm{cm})\end{array}$ & $\mathrm{Fe}$ & S & $\mathrm{Cu}$ & As & Total & $\begin{array}{l}\text { Additional } \\
\text { comments }\end{array}$ \\
\hline $139-856 \mathrm{E}-1 \mathrm{H}-1,106-108$ & 46.30 & 53.30 & 0.08 & 0.00 & 99.68 & Skeletal crystal \\
\hline $\begin{array}{l}\text { 139-856F- } \\
2 \mathrm{X}-\mathrm{CC}, 1-3 \\
2 \mathrm{X}-\mathrm{CC}, 1-3 \\
2 \mathrm{X}-\mathrm{CC}, 1-3 \\
2 \mathrm{X}-\mathrm{CC}, 1-3 \\
2 \mathrm{X}-\mathrm{CC}, 1-3\end{array}$ & $\begin{array}{l}46.80 \\
46.80 \\
46.00 \\
46.10 \\
46.00\end{array}$ & $\begin{array}{l}53.50 \\
53.00 \\
52.80 \\
53.60 \\
52.80\end{array}$ & $\begin{array}{l}0.01 \\
0.00 \\
0.01 \\
0.00 \\
0.00\end{array}$ & $\begin{array}{l}0.00 \\
0.00 \\
0.05 \\
0.07 \\
0.00\end{array}$ & $\begin{array}{r}100.31 \\
99.80 \\
98.86 \\
99.77 \\
98.80\end{array}$ & $\begin{array}{l}\text { Center of a large grain } \\
\text { Margin of the same grain } \\
\text { Skeletal crystal } \\
\text { Center of a euhedral crystal } \\
\text { Margin of the same crystal }\end{array}$ \\
\hline $\begin{array}{l}\text { 139-856G- } \\
\text { 4R-1, 49-51 } \\
\text { 4R-1, 49-51 } \\
\text { 6R-2, 101-103 } \\
\text { 6R-2, 101-103 } \\
\text { 6R-2, 101-103 }\end{array}$ & $\begin{array}{l}46.00 \\
45.50 \\
45.70 \\
46.30 \\
46.70\end{array}$ & $\begin{array}{l}53.40 \\
52.90 \\
53.00 \\
53.00 \\
52.60\end{array}$ & $\begin{array}{l}0.07 \\
0.00 \\
0.00 \\
0.01 \\
0.01\end{array}$ & $\begin{array}{l}0.00 \\
0.00 \\
0.01 \\
0.10 \\
0.08\end{array}$ & $\begin{array}{l}99.47 \\
98.40 \\
98.71 \\
99.41 \\
99.39\end{array}$ & $\begin{array}{l}\text { Grain with magnetite intergrowth } \\
\text { Pyrite without intergrowth } \\
\text { Colloform pyrite } \\
\text { Center of a rounded grain } \\
\text { Margin of the same grain }\end{array}$ \\
\hline $\begin{array}{l}139-856 \mathrm{H}- \\
3 \mathrm{R}-2,67-70 \\
6 \mathrm{R}-1,24-26 \\
9 \mathrm{R}-1,80-82 \\
15 \mathrm{R}-1,60-62 \\
17 \mathrm{R}-1,53-36\end{array}$ & $\begin{array}{l}46.40 \\
47.00 \\
47.00 \\
46.90 \\
46.70\end{array}$ & $\begin{array}{l}53.20 \\
52.60 \\
53.00 \\
52.40 \\
52.80\end{array}$ & $\begin{array}{l}0.01 \\
0.01 \\
0.02 \\
0.02 \\
0.03\end{array}$ & $\begin{array}{l}0.00 \\
0.00 \\
0.05 \\
0.00 \\
0.00\end{array}$ & $\begin{array}{r}99.61 \\
99.61 \\
100.07 \\
99.32 \\
99.53\end{array}$ & $\begin{array}{l}\text { Grain with magnetite, chalcopyrite, and sphalerite intergrowth } \\
\text { Skeletal crystal with sphalerite } \\
\text { Fine-grained aggregate } \\
\text { Anhedral grain } \\
\text { Anhedral grain }\end{array}$ \\
\hline
\end{tabular}

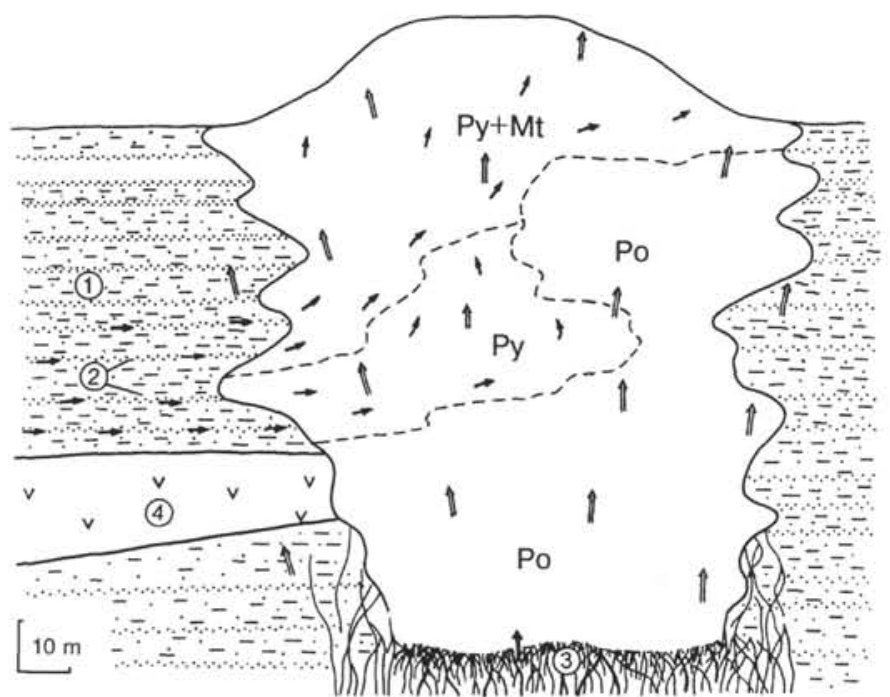

Figure 14. Proposed mechanism of massive sulfide formation and secondary alteration. 1 = unaltered and moderately altered sediments, 2 = turbidite layers, $3=$ stockwork zone, and $4=$ sill emplaced after formation of the sulfide deposit. Zones inside the sulfide deposit: $\mathrm{Po}=$ primary pyrrhotitic sulfide, $\mathrm{Py}=$ secondary pyritic sulfide, and $\mathrm{Py}+\mathrm{Mt}=$ aggregates containing pyrite and magnetite as the main secondary minerals. Paths of primary hydrothermal solutions are shown by open arrows; those of secondary solutions by solid arrows.
Table 10. Representative microprobe analyses $(\mathrm{wt} \%)$ of $\mathrm{Cu}-\mathrm{Fe}$ sulfides.

\begin{tabular}{|c|c|c|c|c|c|}
\hline $\begin{array}{l}\text { Core, section, } \\
\text { interval }(\mathrm{cm})\end{array}$ & $\mathrm{Fe}$ & $\mathrm{Cu}$ & $\mathrm{s}$ & Total & $\begin{array}{l}\text { Additional } \\
\text { comments }\end{array}$ \\
\hline $\begin{array}{l}\text { Chalcopyrite } \\
\text { 139-856F-2X-CC, 1-3 }\end{array}$ & 30.6 & 33.2 & 36.2 & 100.0 & Inclusion in pyrite \\
\hline $\begin{array}{l}139-856 \mathrm{H}- \\
3 \mathrm{R}-2,67-70 \\
9 \mathrm{R}-1,80-82 \\
15 \mathrm{R}-1,60-62 \\
17 \mathrm{R}-1,35-36\end{array}$ & $\begin{array}{l}30.0 \\
30.8 \\
30.2 \\
30.6\end{array}$ & $\begin{array}{l}32.6 \\
33.0 \\
33.2 \\
34.1\end{array}$ & $\begin{array}{l}36.5 \\
36.8 \\
35.3 \\
34.8\end{array}$ & $\begin{array}{r}99.1 \\
100.6 \\
98.7 \\
99.5\end{array}$ & $\begin{array}{l}\text { Inclusion in pyrite } \\
\text { Inclusion in pyrite } \\
\text { Intergrown with pyrite } \\
\text { Intergrown with pyrnhotite }\end{array}$ \\
\hline $\begin{array}{l}\text { Isocubanite } \\
139-856 \mathrm{E}-1 \mathrm{H}-1,106-108\end{array}$ & 41.4 & 23.4 & 36.1 & 100.9 & Intergrown with pyrite and sphalerite \\
\hline $139-856 \mathrm{G}-4 \mathrm{R}-1,49-51$ & 40.5 & 22.6 & 35.5 & 98.6 & Intergrown with chalcopyrite \\
\hline
\end{tabular}

Note: $\mathrm{Zn}, \mathrm{As}, \mathrm{Co}$, and $\mathrm{Cd}$ are below detection limits $(<0,01 \%)$. 
Table 11. Trace element concentrations ( $\mathrm{Au}$ in ppb; all other elements in ppm) in sulfide minerals from massive sulfide samples, determined by INAA.

\begin{tabular}{|c|c|c|c|c|c|c|c|c|c|c|c|c|c|c|c|c|c|c|c|c|c|c|c|c|c|}
\hline $\begin{array}{l}\text { Core, section. } \\
\text { interval }(\mathrm{cm})\end{array}$ & Mineral & $\mathrm{Au}$ & $\mathrm{Ag}$ & As & $\mathrm{Sb}$ & Co & $\mathrm{Ni}$ & $\mathrm{Sc}$ & $\mathrm{Cr}$ & $\mathrm{Zr}$ & Cs & $\mathrm{Rb}$ & $\mathrm{Ba}$ & $\mathrm{Hf}$ & $\mathrm{Ta}$ & Th & $\mathrm{u}$ & $\mathrm{Se}$ & $\mathrm{Hg}$ & La & $\mathrm{Ce}$ & $\mathrm{Sm}$ & Eu & $\mathrm{Tb}$ & $\mathrm{Yb}$ \\
\hline \multicolumn{26}{|l|}{$139-856 \mathrm{G}-$} \\
\hline $2 \mathrm{R}-3,29$ & Cubic, pyrite & na. & 2.0 & n.a. & 11.0 & 2.1 & 19 & 0.20 & 33 & 250 & 0.34 & 30 & 220 & 0.40 & 0.08 & 0.1 & n.a. & 6 & 17 & n.a. & 2.1 & n.a. & 1.00 & 0.28 & 0.39 \\
\hline $3 R-1,61-64$ & Fine-grained pyrite & 114 & 2.0 & n.a. & 4.7 & 11.0 & 12 & 0.93 & 36 & 170 & 0.50 & 16 & 360 & 1.20 & 0.14 & 0.3 & 12.0 & 33 & 5 & 4.6 & n.a. & 3.80 & 0.38 & 0.23 & 0.40 \\
\hline $\begin{array}{l}4 R-1,75-77 \\
6 R-3,95-97\end{array}$ & $\begin{array}{l}\text { Fine-grained pyrite } \\
\text { Cubic pyrite }\end{array}$ & $\begin{array}{l}50 \\
18\end{array}$ & $\begin{array}{l}5.5 \\
6.1\end{array}$ & $\begin{array}{l}16 \\
17\end{array}$ & $\begin{array}{l}2.7 \\
1.2\end{array}$ & 26.0 & $\begin{array}{l}43 \\
46\end{array}$ & $\begin{array}{l}1.20 \\
0.80\end{array}$ & 20 & n.a. & 1.20 & 80 & $\begin{array}{l}240 \\
340\end{array}$ & 2.0 & 0.14 & 0.4 & 2.8 & 26 & n.a. & 2.4 & 7.0 & 1.00 & 1.40 & n.a. & 0.80 \\
\hline $7 \mathrm{R}-1,38-40$ & Fine-grained pyrite & $\begin{array}{r}118 \\
110\end{array}$ & $\begin{array}{l}0.1 \\
4.7\end{array}$ & 130 & 1.0 & 66.0 & 41 & $\begin{array}{l}0.80 \\
0.60\end{array}$ & 56 & $\begin{array}{l}160 \\
90\end{array}$ & $\begin{array}{l}0.16 \\
0.20\end{array}$ & $\begin{array}{l}27 \\
36\end{array}$ & $\begin{array}{l}340 \\
310\end{array}$ & $\begin{array}{l}1.1 \\
0.8\end{array}$ & $\begin{array}{l}0.09 \\
0.09\end{array}$ & $\begin{array}{l}0.3 \\
0.3\end{array}$ & $\begin{array}{l}0.9 \\
2.6\end{array}$ & 16 & 21 & $\begin{array}{l}1.0 \\
<0.5\end{array}$ & 14.0 & $\begin{array}{l}\text { n.a. } \\
0.70\end{array}$ & $\begin{array}{l}1.30 \\
1.50\end{array}$ & $\begin{array}{l}0.30 \\
0.40\end{array}$ & $\begin{array}{l}1.00 \\
\text { n.a. }\end{array}$ \\
\hline \multicolumn{26}{|l|}{$139-856 \mathrm{H}-$} \\
\hline IR-2,4-7 & Cubic, pyrite & 140 & $<1.0$ & 150 & 7.4 & 2.7 & 35 & 0.33 & 68 & 100 & & $<10$ & 580 & 1.2 & 0.09 & 0.3 & 1.3 & 38 & 16 & 1.0 & 6.9 & 0.42 & 0.20 & 0.11 & 0.46 \\
\hline IR-2,4-7 & & 230 & 4.0 & 60 & 6.0 & 2.3 & 12 & 0.30 & 37 & $<100$ & 0.32 & 25 & 2500 & 0.18 & 0.11 & 0.4 & 1.0 & 47 & 4 & $<1.0$ & 13.0 & 0.64 & 0.88 & 0.23 & 0.78 \\
\hline $3 R-1,34-37$ & Fine-grained pyrite & 12 & 4.8 & 4 & 0.4 & 9.6 & $<10$ & 0.70 & $<5$ & n.a. & 0.51 & 16 & 620 & 0.8 & 0.10 & 0.5 & 3.0 & n.a. & n.a. & 1. & 9. & 1.70 & 0.30 & & 1.50 \\
\hline $3 \mathrm{R}$ & Fine-grained pyrite & 131 & 3.2 & n.a. & 0.3 & 33.0 & 67 & 1.60 & 35 & 300 & 0.40 & 47 & 650 & 1.9 & 0.17 & 2.5 & 2.5 & 79 & 42 & 6.2 & 15.0 & n.a. & 0.80 & 0.34 & 1.00 \\
\hline $4 \mathrm{R}-1,18-20$ & Fine-grained pyrite & 37 & 3.5 & 10 & 0.8 & 15.0 & 30 & 1.50 & 12 & 160 & 0.80 & 21 & 500 & 0.8 & 0.20 & 0.6 & 1.7 & 36 & n.a. & 1.1 & 14.0 & 0.20 & 0.50 & n.a. & 0.70 \\
\hline $5 R-1.52-53$ & Cubic, pyrite & 4 & 2.4 & 2 & 0.3 & 10.0 & 16 & 0.60 & 29 & 110 & 0.50 & 31 & 480 & n.a. & 0.10 & 0.6 & 4.5 & 88 & 22 & 1.0 & 3.0 & 0.90 & 0.30 & 0.49 & 1.80 \\
\hline $7 \mathrm{R}-1$, & Fine-grained pyrit & 30 & 3.1 & 3 & 0.4 & 11.0 & 15 & 0.70 & $<5$ & 200 & 0.50 & 35 & 200 & 0.8 & 0.08 & 0.3 & 5.1 & 10 & n.a. & 1.2 & 20.0 & 1.60 & 0.60 & 0.30 & 1.30 \\
\hline 126 & Fine-gri & 36 & 7.4 & 130 & 6.5 & 84.0 & 66 & 0.40 & 47 & 120 & 0.53 & 77 & $0.1 \%$ & 0.9 & 0.30 & 0.8 & 2.8 & 16 & 20 & 1.0 & n.a. & 0.80 & n.a. & n.a. & 1.50 \\
\hline $9 \mathrm{R}-1,80-82$ & Fine-grained & 60 & 1.5 & 78 & 3.8 & 20.0 & 20 & 0.40 & 19 & 82 & 0.34 & 32 & 660 & 2.1 & $<0.05$ & $<0.1$ & 1.2 & 8 & 10 & 0.7 & 24.0 & 0.40 & a. & 0.15 & 1.00 \\
\hline $\begin{array}{l}\text { IIR-1, 49-51 } \\
14 R-1,46\end{array}$ & $\begin{array}{l}\text { Fine-grained pyrite } \\
\text { Pomblymblastic nyvit }\end{array}$ & $\begin{array}{l}90 \\
16\end{array}$ & $\begin{array}{l}1.7 \\
2.5\end{array}$ & $\begin{array}{r}66 \\
2\end{array}$ & $\begin{array}{l}3.7 \\
0.3\end{array}$ & 59,0 & 18 & $\begin{array}{r}0.50 \\
0.70\end{array}$ & 15 & 60 & 0.30 & 39 & 180 & 0.5 & 0.06 & 0.3 & 3.0 & 12 & 15 & 1.0 & n.a. & 0.90 & 0.40 & 0.40 & n.a. \\
\hline & & & & & & & & & & & & & & & & & & & & & & & & & \\
\hline $\begin{array}{l}19 \text { samples from } \\
\text { sediment-free ridges }\end{array}$ & Pyrite & 370 & 12.0 & 26 & 10.5 & 1910.9 & 86 & 2.80 & 85 & 820 & 1.32 & 151 & 976 & 4.0 & 0.27 & 1.8 & 0.8 & 26 & n.a. & 2.3 & 9.1 & 0.70 & 0.87 & 0.45 & 1.14 \\
\hline & Pyrrhotite & 17 & 3.0 & 2 & 0.3 & 12.0 & 12 & 0.60 & 39 & 170 & 0.70 & 25 & 90 & $<0.5$ & 0.20 & 0.3 & 0.5 & 130 & 52 & 2.0 & 19.0 & 0.20 & 0.30 & 0.51 & 7.20 \\
\hline $139-856 \mathrm{H}-5 \mathrm{R}-1.52-53$ & Sphalerite & 36 & 7.4 & 7 & 0.7 & 4.5 & 140 & 21.0 & 50 & 640 & $<0.10$ & 85 & 820 & 3.6 & 0.30 & 0.7 & 43.0 & 40 & 16 & 2.7 & 12.0 & 0.50 & 0.70 & n.a. & 1.10 \\
\hline $\begin{array}{l}22 \text { samples from } \\
\text { sediment-free ridges }\end{array}$ & Zinc sulfides & 470 & 129.0 & 146 & 27.7 & 113.0 & 174 & 4.20 & 127 & 2039 & 3.74 & 128 & 1777 & 7.0 & 0.62 & 2.3 & 1.0 & 42 & n.a. & 2.8 & 18.0 & 2.63 & 2.75 & 1.18 & 2.52 \\
\hline
\end{tabular}

Note: n.a. = not analyzed. Data on sulfides from sediment-free ridges are median values from previous studies (Krasnov et al., 1992). 